Article

\title{
Biosynthesis of Selenium Nanoparticles (via Bacillus subtilis BSN313), and Their Isolation, Characterization, and Bioactivities
}

\author{
Asad Ullah 1,2,3 ${ }^{1}$, Xian Yin ${ }^{1,2}$, Fenghuan Wang 1,2,*(D), Bo Xu ${ }^{4, *}$, Zulfiqar Ali Mirani ${ }^{3}$, Baocai Xu ${ }^{1,2}$, \\ Malik Wajid Hussain Chan ${ }^{5}$, Amjad Ali ${ }^{5}$, Muhammad Usman ${ }^{1}$, Nawazish Ali 1,2 and Muhammad Naveed ${ }^{1,2}$
}

1 Beijing Advanced Innovation Center for Food Nutrition and Human Health, Beijing Technology \& Business University (BTBU), Beijing 100048, China; asadbahi2016@gmail.com (A.U.); yinxian@btbu.edu.cn (X.Y.); xubaoc@btbu.edu.cn (B.X.); ch.usman1733@gmail.com (M.U.); alibtbu@gmail.com (N.A.); nnourang@yahoo.com (M.N.)

2 School of Light Industry, Beijing Technology \& Business University (BTBU), Beijing 100048, China

3 Food and Marine Resources Research Center, Pakistan Council of Scientific and Industrial Research Laboratories Complex, Karachi 75280, Pakistan; mirani_mrsa@yahoo.com

4 McIntire School of Commerce, University of Virginia, Charlottesville, VA 22903, USA

5 Centre of Excellence in Marine Biology, University of Karachi, Karachi 75270, Pakistan; chanwajid@gmail.com (M.W.H.C.); amjadalimb@uok.edu.pk (A.A.)

* Correspondence: wangfenghuan@th.btbu.edu.cn (F.W.); bx2pw@virginia.edu (B.X.)

check for updates

Citation: Ullah, A.; Yin, X.; Wang, F.; Xu, B.; Mirani, Z.A.; Xu, B.; Chan, M.W.H.; Ali, A.; Usman, M.; Ali, N.; et al. Biosynthesis of Selenium Nanoparticles (via Bacillus subtilis BSN313), and Their Isolation, Characterization, and Bioactivities. Molecules 2021, 26, 5559. https:// doi.org/10.3390/molecules26185559

Academic Editor: Claus Jacob

Received: 23 August 2021

Accepted: 8 September 2021

Published: 13 September 2021

Publisher's Note: MDPI stays neutral with regard to jurisdictional claims in published maps and institutional affiliations.

Copyright: (c) 2021 by the authors. Licensee MDPI, Basel, Switzerland. This article is an open access article distributed under the terms and conditions of the Creative Commons Attribution (CC BY) license (https:// creativecommons.org/licenses/by/ $4.0 /)$.
Abstract: Among the trace elements, selenium (Se) has great demand as a health supplement. Compared to its other forms, selenium nanoparticles have minor toxicity, superior reactivity, and excellent bioavailability. The present study was conducted to produce selenium nanoparticles (SeNPs) via a biosynthetic approach using probiotic Bacillus subtilis BSN313 in an economical and easy manner. The BSN313 exhibited a gradual increase in Se reduction and production of SeNPs up to $5-200 \mu \mathrm{g} / \mathrm{mL}$ of its environmental Se. However, the capability was decreased beyond that concentration. The capacity for extracellular SeNP production was evidenced by the emergence of red color, then confirmed by a microscopic approach. Produced SeNPs were purified, freeze-dried, and subsequently characterized systematically using UV-Vis spectroscopy, FTIR, Zetasizer, SEM-EDS, and TEM techniques. SEM-EDS analysis proved the presence of selenium as the foremost constituent of SeNPs. With an average particle size of $530 \mathrm{~nm}$, SeNPs were shown to have a $-26.9(\mathrm{mV})$ zeta potential and $-2.11 \mu \mathrm{m} \mathrm{cm} / \mathrm{Vs}$ electrophoretic mobility in water. SeNPs produced during both the 24 and $48 \mathrm{~h}$ incubation periods showed good antioxidant activity in terms of DPPH and ABST scavenging action at a concentration of $150 \mu \mathrm{g} / \mathrm{mL}$ with no significant differences $(p>0.05)$. Moreover, $200 \mu \mathrm{g} / \mathrm{mL}$ of SeNPs showed antibacterial reactivity against Escherichia coli ATCC 8739, Staphylococcus aureus ATCC 9027, and Pseudomonas aeruginosa ATCC 25923. In the future, this work will be helpful to produce biogenic SeNPs using probiotic Bacillus subtilis BSN313 as biofactories, with the potential for safe use in biomedical and nutritional applications.

Keywords: selenium; SeNPs; probiotic; Bacillus subtilis BSN313; antioxidant; antibacterial

\section{Introduction}

Selenium (Se) is an important cofactor for antioxidant enzymes such as glutathione peroxidase and thioredoxin reductase [1,2], and its deficiency can damage the liver, heart, kidneys, skeletal muscle, and testes [3]. However, doses above $400 \mu \mathrm{g} /$ day can be toxic, and can cause diabetes and prostate cancer [4-6]. Se toxicity may arise through mechanisms such as oxidative stress or substitution of selenium for sulfur during protein assembly $[7,8]$. However, this toxicity depends on the forms of Se. For example, selenium nanoparticles (SeNPs) show better bioavailability and less toxicity compared to inorganic (sodium selenite) forms [9]. 
Selenium is crucial for the body due to its ability to affect the activity of the selenoenzyme glutathione peroxidase, and to protect cells and tissues from damage, acting as an antioxidant. It is possible that selenium is useful in the prevention of various diseases, including cardiovascular disease, arthritis, muscular dystrophy, and cystic fibrosis [10]. Selenium is widely used as a dietary supplement [11-13], particularly because of its relationship with the immune system, and can be used for the treatment of cancer [14]. The interaction of selenium with heavy metals is well known. Selenium compounds are believed to be detoxifying agents, playing an antagonistic role towards mercury, methylmercury [15-18], cadmium [19], silver [20], lead [21], and many other elements [14].

The specific properties of selenium nanoparticles of various sizes and shapes, compared to Se's metallic form, have significant application in medicine, including for cancer treatment [22], drug synthesis [23], DNA study [24], magnetic resonance imaging [25], biosensors [26], environmental rehabilitation [27], and pharmaceuticals [28], as well as agricultural [29], electronics, and commercial uses [30].

Selenium nanoparticles (SeNPs) have distinct chemical and physical properties due to their large surface-volume ratio, large surface energy, spatial limitation, and reduced imperfections [31]. The selenium nanoparticles (SeNPs) have numerous applications, particularly in medication, due to therapeutic effects such as low toxicity, better reactivity, low required dosage, and excellent bioavailability compared to other oxidation states of selenium (Se), such as $\mathrm{Se}^{6+}$ and $\mathrm{Se}^{4+}$ [32-35]. For the biological activities of Se, SeNPs are regarded as better than the other forms of Se due to their greater biological activity and low toxicity [36].

Nanoparticles can be synthesized by both organic and inorganic means [36]. The biomedical use of inorganic nanoparticles (NPs) has attracted increasing interest in the past few decades. However, in the last couple of years, the interest in nanotoxicology has increased, and more data regarding the cytotoxic properties of inorganic NPs have been reported. Several reviews present an overview of the most important findings on this topic [37-41]. The biogenic nanoparticles are considered to be relatively safe for both human and animal use [42,43]. The microorganisms employ a detoxification mechanism for the reduction of selenites/selenates to nano-selenium, and are referred to as potential biofactories for the synthesis of well-defined selenium nanoparticles [1].

Some comparisons indicate that biogenic techniques are safer and more affordable than other techniques. In non-biogenic techniques, instrumental or chemical methods are used;the instruments required are very expensive [44]. Evaporation and laser ablation techniques are examples of instrumental methods, generally used for the synthesis of nanoparticles [45]. In chemical techniques, additives, solvents, and stabilizers such as borohydride, ethaline, dodecanthiolates, and many other chemicals are applied. These chemicals are not eco-friendly, are hazardous, and are toxic for living beings [44]. Ultimately non-biogenic techniques make the nanoparticles unsafe for biomedical and nutritional uses, while biogenic techniques are safe, inexpensive, eco-friendly, and nontoxic [33,46,47].

The nanoparticles synthesized by microbes have versatile applications and advantages compared to those derived from other, conventional processes [48]. Biogenic SeNPs are more stable, and do not aggregate, owing to the natural coating of the biomolecules [33]. Some microbes—such as yeasts, fungi, and bacteria-are used to produce SeNPs, as they are capable ofsurviving and growing in the selected concentrations of selenium, andcan reduce toxic ions into distinct nanoparticles $[49,50]$. Bacterial reductions of selenate or selenite occurboth anaerobically and aerobically, by non-enzymatic or enzymatic mechanisms. This biotransformation leads to the formation of cytoplasmic, periplasmic, or extracellular SeNPs [51]. Amongst all of the microbes, bacteria are the best choice for the synthesis of nanoparticles [52], due to their fast growth rate, easy handling, low cost, and high productivity [2].

Over the past 10 years, many aerobic and anaerobic bacteria have been reported to have the capability of inorganic selenium $\left(\mathrm{SeO}_{3}{ }^{2-}\right.$ and/or $\left.\mathrm{SeO}_{4}{ }^{2-}\right)$ reduction with the immediate formation of extra/intracellular SeNPs, e.g., Escherichia coli ATCC 35,218 [53], re- 
combinant E. coli [54], Ralstoniaeutropha [24,52], Enterobacter cloacae Z0206 [55], Pseudomonas aeruginosa ATCC 27,853 [56], Klebsiella pneumonia [30,31,57,58], Pantoeaagglomerans [14,35], Zooglearamigera [2,25], Rhodopseudomonaspalustris strain N [59], Shewanella sp. HN-41 [60], Azoarcus sp. CIB [61], Burkholderiafungorum [35,62], Stenotrophomonasmaltophilia [36,63], Staphylococcus carnosus [37,64], Lactobacillus casei $[58,65,66]$, Lactobacillus acidophilus LA-5, LactobacillushelveticusLH-B02, Streptococcus thermophilus, Bifidobacterium BB-12 [65], Enterococcus faecalis [67], Bacillus sp. MSh-1 [68,69], Bacillus subtilis [70], Bacillus mycoides SelTE01 [71], Bacillus licheniformis JS2 [72], Bacillus megaterium [73], Streptomyces sp. ES25 [74], etc. SeNPs have fascinating potential biological applications, such as antioxidant and antimicrobial uses [75-82]. Among these, the nonpathogenic/probiotic bacteria could be more suitable tools for the production of SeNPs for utilization for medical and nutritional purposes.

In this study, the selenium nanoparticle (SeNP)-producing ability of probiotic Bacillus subtilis BSN313 was studied. Produced SeNPs were characterized by UV-Vis spectroscopy, Fourier-transform infrared (FTIR), and morphological studies carried out via scanning electron microscopy (SEM) coupled with energy-dispersive spectroscopy (EDS) and transmission electron microscopy (TEM). The selenium nanoparticles (SeNPs) produced during the 24 and $48 \mathrm{~h}$ incubation periods also showed antioxidant activity in DPPH and ABST assays. Moreover, these SeNPs were also tested for antibacterial reactivity against E. coli, $S$. aureus, and $P$. aeruginosa.

\section{Results}

\subsection{SeNP Synthesis Capability}

In order to envisage this potential, the probioticwas grown in LB solid agar containing $1-10 \mu \mathrm{g} / \mathrm{mL}$ of selenium as sodium selenite. The appearance of reddish colonies at $6 \mu \mathrm{g} / \mathrm{mL}$ Se (Figure 1a) was the first evidence of selenite reduction, followed by formation of SeNPs. In order to monitor the ability of the strain to produce biogenic SeNPs, it was aerobically (200 rpm) grown for a further 24 and $48 \mathrm{~h}$ at $37^{\circ} \mathrm{C}$ in liquid LB medium in the presence of a wide range of concentrations of Se $(5-600 \mu \mathrm{g} / \mathrm{mL})$ in the medium. The results are presented in Figure 2. After $5 \mathrm{~h}$, the growing culture was started to turn a red color, which was an indication of the reduction of $\mathrm{Se}$ into $\mathrm{Se}^{0}$. The significant reddish color was not observed at a low concentration of Se $(5 \mu \mathrm{g} / \mathrm{mL})$, but started to appear gradually at greater concentrations. At a concentration of $100 \mu \mathrm{g} / \mathrm{mL}$ (Se in the medium) $93.1 \%$ and $98.33 \%$ of Se was reduced into $\mathrm{Se}^{0}$ when incubation was continued to 24 and $48 \mathrm{~h}$, respectively. However, the total $\mathrm{Se}^{0}$ content in the SeNPs steadily increased, and was found to be higher at $200 \mu \mathrm{g} / \mathrm{mL}$, though it dropped at higher concentrations. Nevertheless, the strain was able to transform $>93.1 \%$ of environmental Se $(100 \mu \mathrm{g} / \mathrm{mL})$ in $24 \mathrm{~h}$, despite the SeNP yield being highest at $200 \mu \mathrm{g} / \mathrm{mL}$.

The proficiency of Bacillus subtilis BSN313 in synthesizing extracellular SeNPs was confirmed when it was observed under the microscope at a magnification of $\times 400$ (Figure 3a). At the same magnification, the purification of SeNPs from the cell suspension was also ensured (Figure 3b). These acquired results confirmed that bacterial strain BSN313 effectively reduced Se to elemental $\mathrm{Se}^{0}$ at the maximum level during the log growth phase. The Se biotransformation capability patterns at both 24 and $48 \mathrm{~h}$ were similar, and the SeNP yield was not remarkably high at $48 \mathrm{~h}$ (Figure 2). Therefore, SeNPs were produced in bulk for $24 \mathrm{~h}\left(200 \mathrm{rpm}, 37^{\circ} \mathrm{C}\right.$, and $200 \mu \mathrm{g} / \mathrm{mL}$ Se) for subsidiary characterization. 


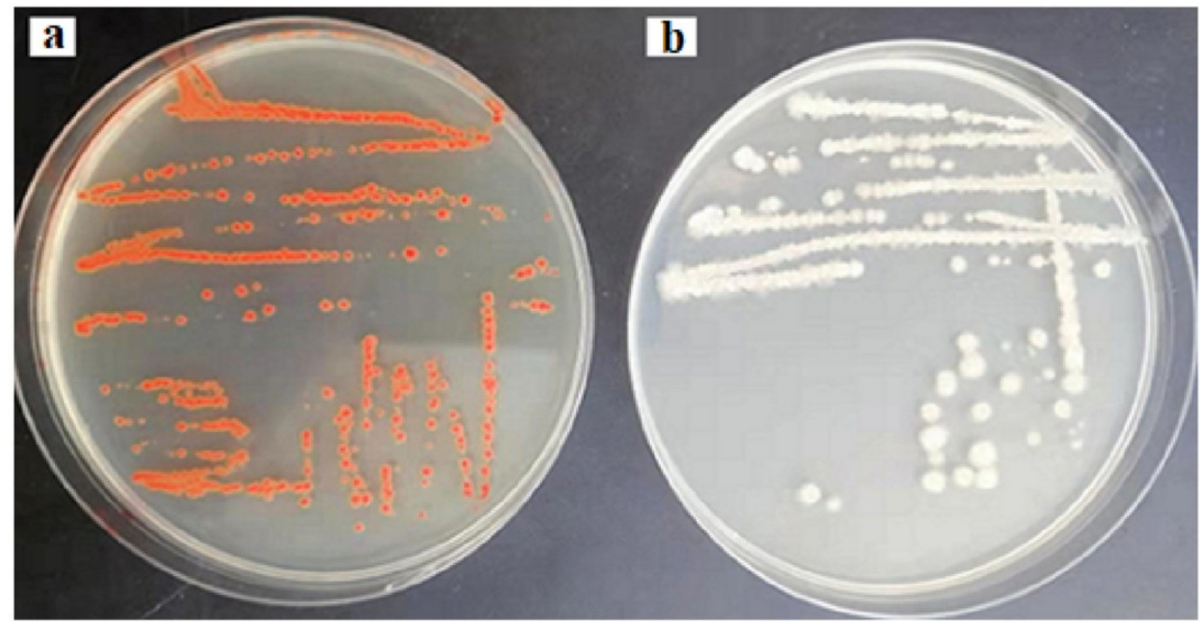

Figure 1. Reddish colonies of BSN313 in the presence of $6 \mu \mathrm{g} / \mathrm{mL}$ Se in Luria Broth (LB) (a) and control (b).
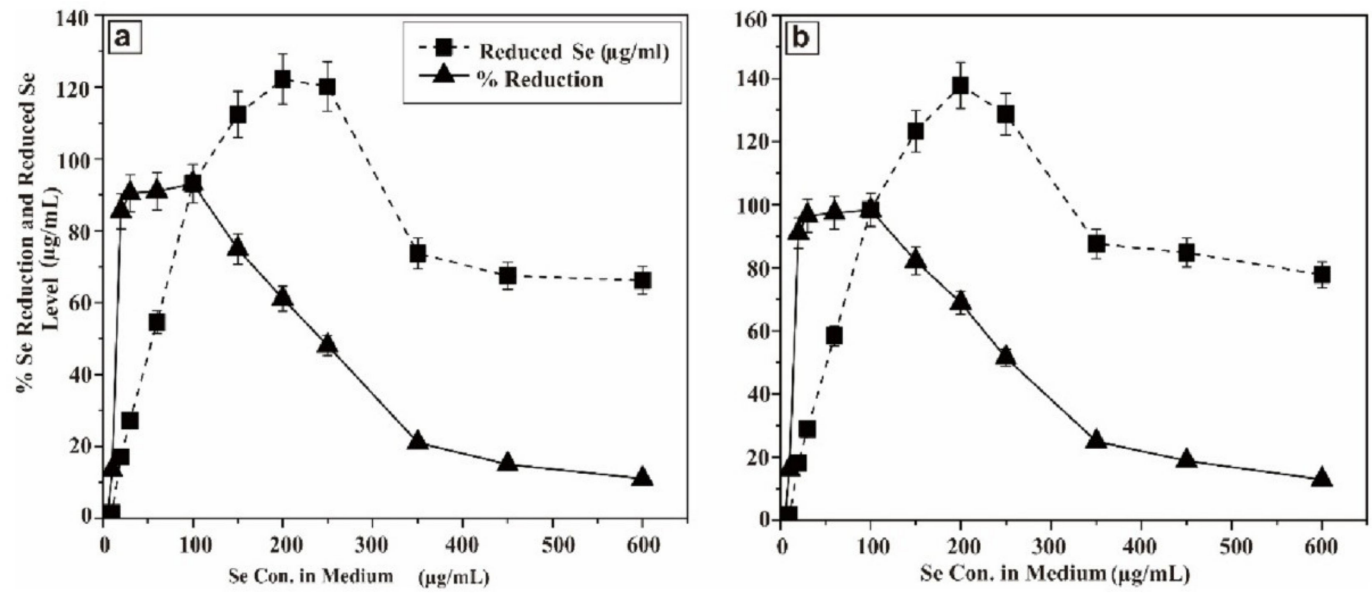

Figure 2. Se reducing capability of BSN313 at $24 \mathrm{~h}$ of incubation (a) and (b) Se reducing capability of BSN313 at $48 \mathrm{~h}$ of incubation.
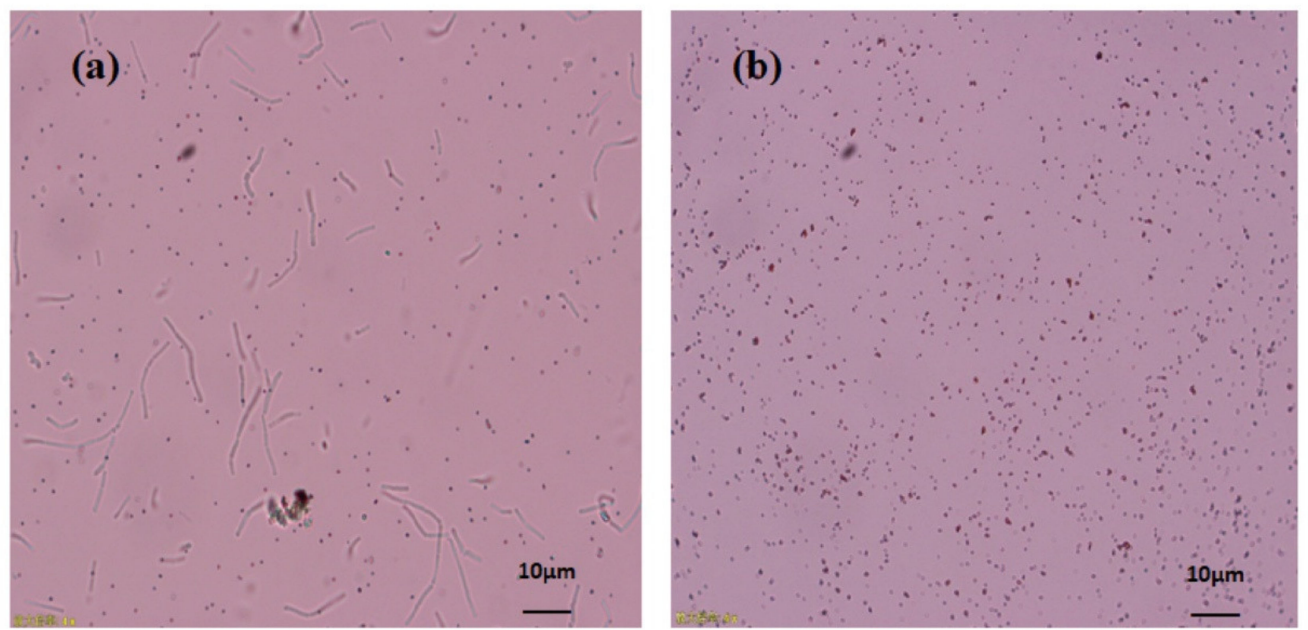

Figure 3. Microscopic image of extracellular SeNPs, before purification (a), after purification (b). 


\subsection{Characterization of SeNPs}

The UV visible absorption spectrum of purified SeNPs was presented in Figure 4a. The UV-Visible absorption spectra (300-800 nm) of SeNPs produced by BSN313, shown a small transition point at nearby $362 \mathrm{~nm}$ and have a maximum absorption peak at $650 \mathrm{~nm}$. The earlier reports for the biosynthesis of SeNPs were also recorded in the literature [83,84]. Fourier transform infrared (FTIR) spectrum of the SeNPs was presented in Figure $4 \mathrm{~b}$. Through FTIR, stretching and bending bands of different functional groups $(\mathrm{OH}, \mathrm{HN}$, $\mathrm{CO}, \mathrm{CN})$, giving the spectral peaks e.g.the peak at $3477 \mathrm{~cm}^{-1}$ indicated the $\mathrm{OH}$ stretching of the free or intermolecular bonded alcoholic group. The peak at $1406 \mathrm{~cm}^{-1}$ may be attributed to the $\mathrm{O}-\mathrm{H}$ bending of carboxylate. The peak at $1636 \mathrm{~cm}^{-1}$ showed the amide $\mathrm{N}-\mathrm{H}$ bending or any $\mathrm{C}=\mathrm{O}$ stretch of the ester group while the peak at $1104 \mathrm{~cm}^{-1}$ evidenced the C-N stretching of the amine as well. The absorption peaks of the NPs may represent to stretching, bending and vibrational frequencies of certain organic functional groups such as $\mathrm{NH}_{2}, \mathrm{COOH}, \mathrm{CH}_{2}$ and $\mathrm{CO}$, recorded in the previous literature $[85,86]$.
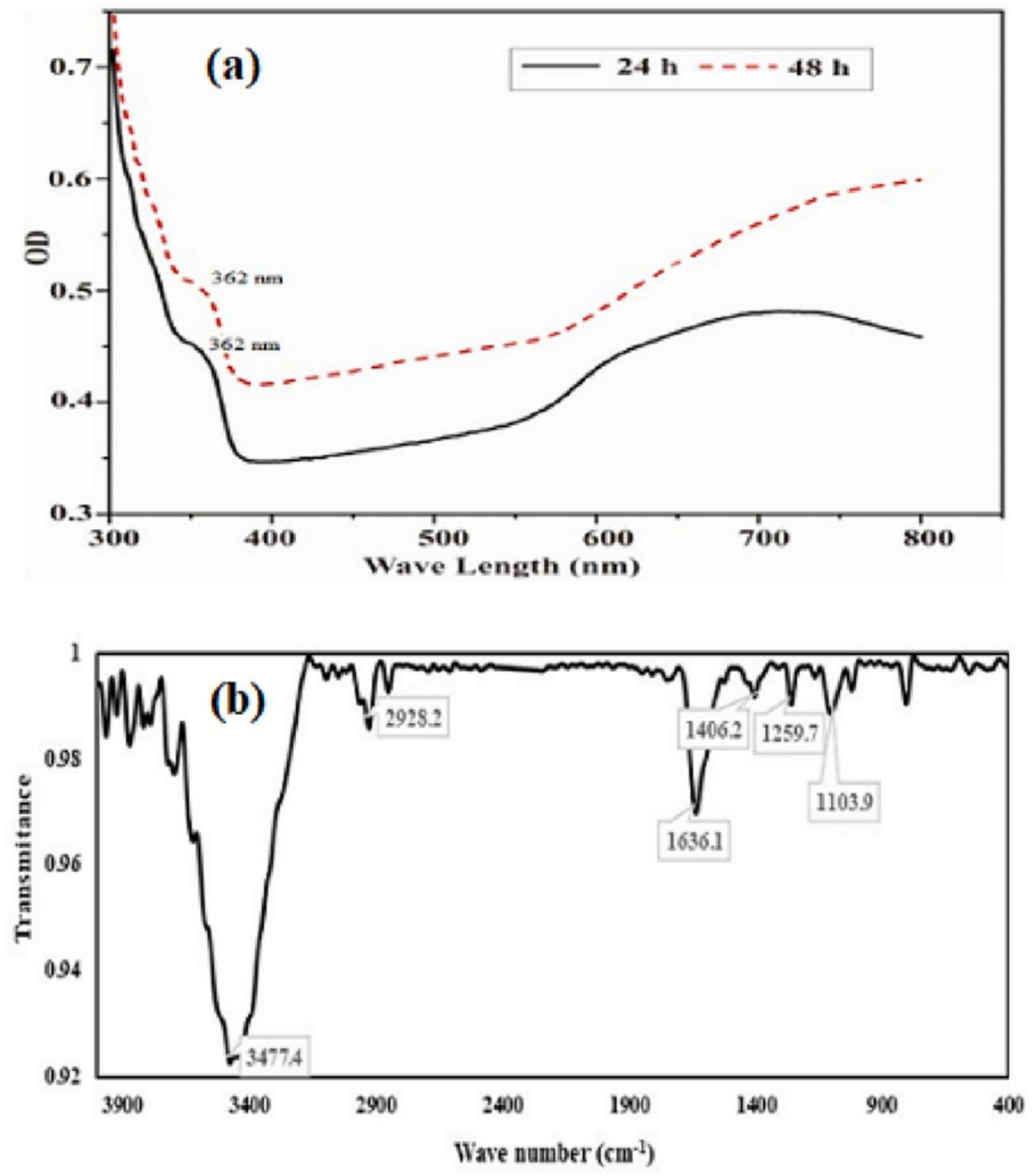

Figure 4. UV/visible (a) and FTIR spectra (b) of purified SeNPs formed by BSN313 during $24 \mathrm{~h}$.

During biosynthesis of SeNPs carbohydrates and amino groups might be involved, the carbohydrates combine with amino groups bind tightly to the surface of the SeNPs. The use of reducing end chemistry introduces one amino group per carbohydrate (polysaccharide) chain, and provides an excellent way of measuring the exact amount of polysaccharides loaded on the surface of nanoparticle [87].

The results of particle size, zeta potential (ZP), and electrophoretic mobility (EPM) were presented in Figure 5. The particle size of purified SeNPs was found to be an average of $530 \mathrm{~nm}$ when tested by Zetasizer. The zeta potential remains an important 
indicator of the stability of the colloidal dispersion of nanoparticles. The ZP of freeze dried SeNPs of BSN313 was observed $-26.9(\mathrm{mV})$ when suspended in deionized water. Zeta potential is the measure of an effective electric charge on the surface of nanoparticles. The nanoparticles with higher magnitude of Zeta potential exhibits increased stability due to greater electrostatic repulsion between nanoparticles. Our result is accordance with the literature $[79,88]$.
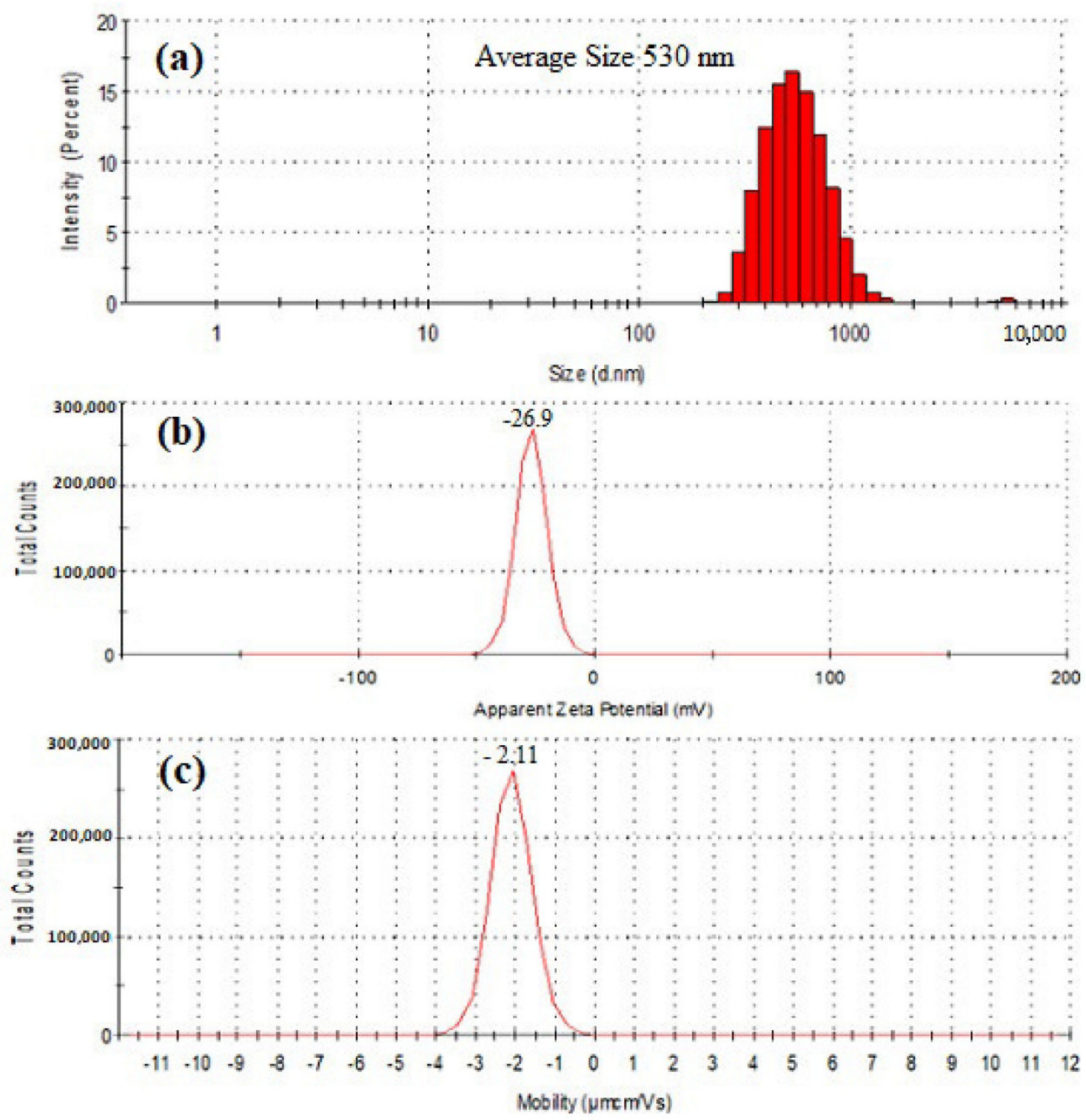

Figure 5. Particle size distribution (a), Zeta potential (b) and electrophoretic mobility (c) of SeNPs produced by BSN313 during $24 \mathrm{~h}$.

The negative symbol in the zeta potential means that the net charge of the object is negative. Basic groups have negative charges on their surface [89]. In this study, the SeNPs have amino groups (N-H). The available lone pair of electron on the N-H group makes them electron rich so the net charge remains negative. The attendence of reducing agents $(\mathrm{N}-\mathrm{H})$, among the SeNPs, favors them to exist in dispersed form [77]. Same kind of observation was recorded in the previous literature [79,90].

The morphology characterization of SeNPs was studied through the TEM and SEMEDS analysis. Figure $6 a, b$ shown the TEM images of the purified SeNPs at a resolution of $120 \mathrm{~nm}$ scale. SeNPs were amorphous and/or spherical in shape and size distribution of manual counting of 50 particles from different TEM images showed that most of the 
SeNPs were in the range of 280-630 $\mathrm{nm}$. However, the results proved that the nanoparticles have a variable size and were dispersed in an aqueous solution. Figure $6 c, d$ shown the representative SEM micrograph of purified SeNPs, where spherical and/or amorphous shaped Se nanoparticles with some aggregates of different lengths were seen. Elemental analysis of SeNPs was established via the EDS coupled SEM. EDS spectrum was presented in Figure $6 \mathrm{e}, \mathrm{f}$ which confirmed the presence of Se entirely in the nanoparticles.
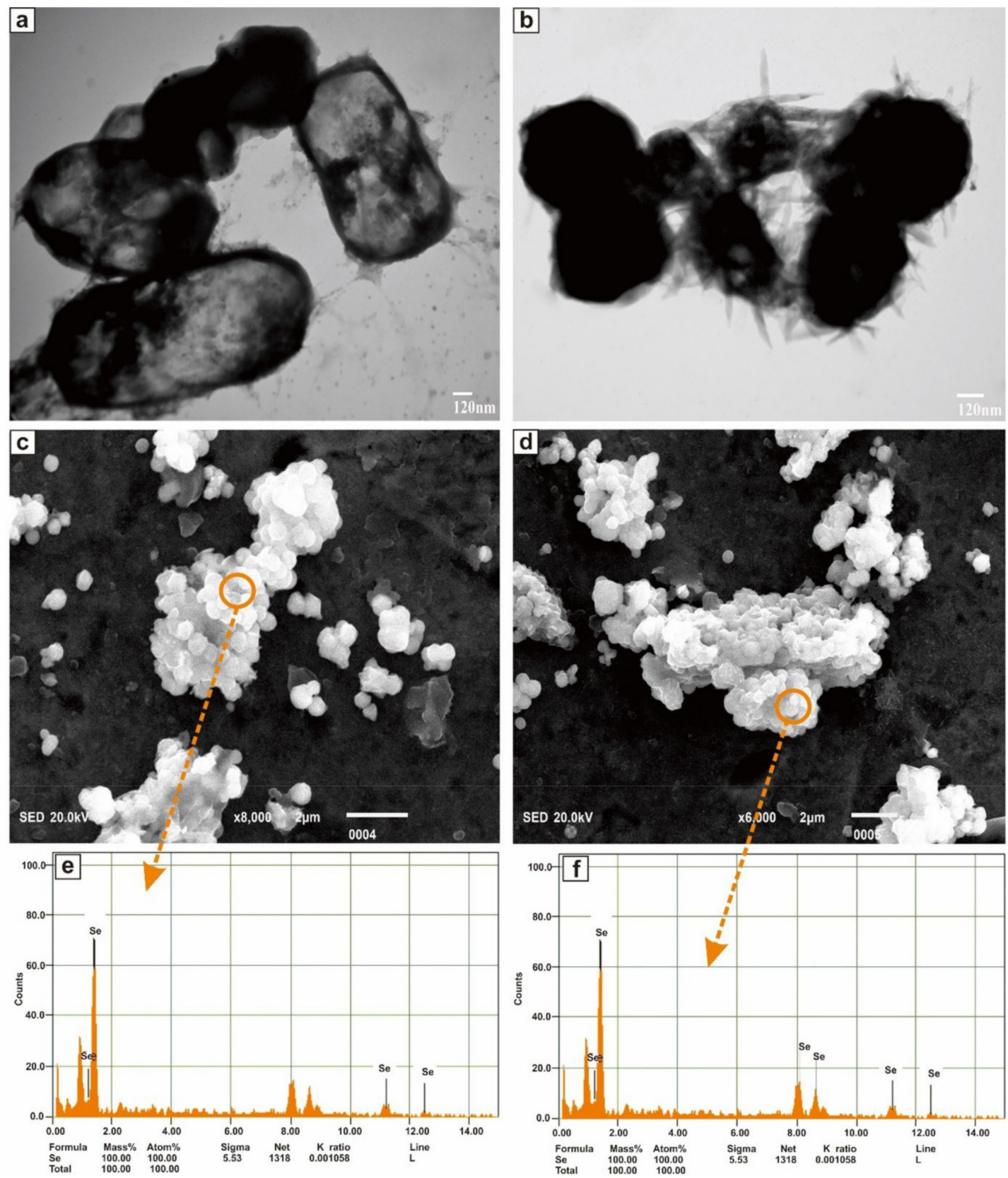

Figure 6. TEM images (a,b), SEM images (c,d), and EDS spectra (e,f) of purified SeNPs produced by BSN313 during 24 h.

\subsection{Bioactivities of SeNPS}

SeNPs produced at 24 and $48 \mathrm{~h}$ shown (Table 1) some good antioxidant (DPPH and ABTS scavenging) properties with no significant difference $(p>0.05)$. At the concentration of $150 \mu \mathrm{g} / \mathrm{mL}$ DPPH scavenging ability was found to be 71.25 and $70.40 \%$ in 24 and $48 \mathrm{~h}$ respectively. At the same concentration, the ABTS free radical scavenging potential was found 63.01 and $60.61 \%$ in both 24 and 48 h correspondingly. 
Table 1. Antioxidant and antibacterial effects of SeNPs produced by BSN313.

\begin{tabular}{ccc}
\hline & 24 h & $\mathbf{4 8 ~ h}$ \\
\hline DPPH $(\%)$ & $71.25 \pm 2.81^{\mathrm{a}}$ & $70.40 \pm 2.67^{\mathrm{a}}$ \\
\hline ABTS $(\%)$ & $63.01 \pm 2.74^{\mathrm{a}}$ & $60.61 \pm 3.03^{\mathrm{a}}$ \\
\hline E. Coli ATCC $8739(\mathrm{~mm})$ & $11.3 \pm 0.58^{\mathrm{a}}$ & $11.3 \pm 0.58^{\mathrm{a}}$ \\
\hline P. aeruginosa ATCC $25923(\mathrm{~mm})$ & $12 \pm 1.0^{\mathrm{a}}$ & $12 \pm 1.0^{\mathrm{a}}$ \\
\hline S. aureus ATCC 9027 $(\mathrm{mm})$ & $15 \pm 1.0^{\mathrm{a}}$ & $15 \pm 0.58^{\mathrm{a}}$ \\
\hline a Data with the same superscript letters indicate no significant differences $(p>0.05), n=3$.
\end{tabular}

SeNPs formed at 24 and $48 \mathrm{~h}$ also shown a substantial growth inhibition at a concentration of $200 \mu \mathrm{g} / \mathrm{mL}$ against E. coli ATCC 8739, P. aeruginosa ATCC 25923 and S. aureus ATCC 9027 with 11,12, and $15 \mathrm{~mm}$ inhibition zones respectively. Overall, the antimicrobial effect of SeNPs produce at $24 \mathrm{~h}$ and $48 \mathrm{~h}$ was found not significantly different $(p>0.05)$.

\section{Discussion}

These data suggested that the rate and efficiency of formation of $\mathrm{Se}^{0}$ are most likely related to both; the total number of bacterial cells (concentration) and incubation time of the bacterium. However, the incubation period is more important. Delay formation of $\mathrm{Se}^{0}$ by improving the growth conditions is the best strategy for maximum microbial Se enrichment. It means, the concentration of $\mathrm{Se}^{0}$ depends on the incubation period of the microbes. By increasing the incubation time, more enzymatic proteins released by the bacterium, which reduce the ionic selenium $\left(\mathrm{SeO}_{3}{ }^{2-}\right)$ to $\mathrm{Se}^{0}[91,92]$. E. coli ATCC 35218 was similarly reported to shown $89.2 \%$ of Se $(1 \mathrm{mM})$ reduction capability within $72 \mathrm{~h}$ of incubation in nutrient broth at $37^{\circ} \mathrm{C}$ [53]. In the same way, a decreased in Se concentration (by K. pneumonia) was recorded from 200 to $80 \mathrm{ppm}$ in culture media when incubated for $24 \mathrm{~h}$ at $37^{\circ} \mathrm{C}$ [57]. The microbes transform, ionic Selenium into non-toxic zero valent selenium nanoparticles which can bemore bioavailable selenium source for human and animal nutrition [93].

This study is an extension of our previous work, isolation of selenium-resistant bacteria (Bacillus subtilis BSN313) from the selenium enriched medium. This probiotic strain has the higher capability to show resistance in selenium enriched medium. BSN313 strain would safely be used as a probiotic tool for the production of SeNPs for nutritional and medicinal purpose [94]. So the present study was designed for developing probiotic nano-selenium containing products/selenium nano-sized particles (SeNPs) via a biosynthetic approach using probiotic Bacillus Subtilis BSN313 in an economic and easy way. Characterization of nanoparticles and their therapeutic applications were also analyzed in the present study. The BSN313 exhibited a gradual increase in Se reduction and production of selenium nano-sized particles (SeNPs) from selenium enriched media $(600 \mu \mathrm{g} / \mathrm{mL})$. Bacillus subtilis BSN313 reduced the soluble, toxic, colorless selenium ions to the insoluble, non-toxic, red elemental SeNPs.

At the concentration of $100 \mu \mathrm{g} / \mathrm{mL}$ (Se in the medium), more than $95 \%$ ionic Se was reduced into $\mathrm{Se}^{0}$ after $48 \mathrm{~h}$. During the $\log$ phase of Bacillus subtilis BSN313, the reduction phase $\left(\mathrm{Se}^{0}\right)$ occurred. Same kind of observations were recorded in the same genus, reported in the previous literature $[68,70,95]$. However, the total reduction occurred, when the concentration of the selenium in the medium was increased to $200 \mu \mathrm{g} / \mathrm{mL}$. By increasing the selenium concentration in the growth medium, the reduction process began to decrease gradually and stopped at $600 \mu \mathrm{g} / \mathrm{mL}$.

Morphological changes (nanoparticle size and agglomeration) were observed for SeNPs dispersion by using UV-Vis spectrophotometry. The absorption bands with maxima located between $300-800 \mathrm{~nm}$. The characteristic spectrum was not accurately matched with the previously reported spectra of even SeNPs produced by bacillus species $[70,73,96,97]$. A number of reports discussed the spectra of SeNPs and confirmed that the distinguish 
spectral peak of SeNPs was based on chemical arrangement, shape, particle size, and growth conditions [98-102].

In the present study SeNPs synthesis was mediated by B. subtilis BSN313. When sodium selenite was added to B. subtilis BSN313 culture, the reddish colour indicating the formation of SeNPs $[49,103,104]$. FTIR spectroscopy is used to confirm the presence of functional groups which were mainly involved in the SeNPs bioreduction process. The FTIR spectrum pattern of SeNPs showed different functional groups at the surface of the SeNPs which may be responsible for the reduction of sodium selenite (inorganic form) to the organic form (SeNPs) [97]. Stretching and bending bands of different groups $(\mathrm{OH}, \mathrm{NH}$, $\mathrm{CO}, \mathrm{CN}$ ), confirmed the spectrum of biogenic SeNPs synthesized by Bacillus subtilis BSN313. The Broad absorbtion bands, corresponding to the reducing groups $(\mathrm{C}-\mathrm{O}, \mathrm{NH}, \mathrm{C}-\mathrm{C})$ present in the bacterial proteins which were responsible for the reduction of sodium selenite into SeNPs. The overall FTIR spectral fingerprint pattern was in agreement with the outline of SeNPs produced by Ramya et al., (2015), Mehta et al., (2021) and Alvi et al., (2021) [105-107] via a green synthesis approach. The previous literature indicated, the presence of some biomolecules may have reducing power to synthesize the nanoparticles. Polysaccharides have many functionalities including hydroxyl groups and a hemiacetal reducing end that are capable of reducing precursor salts. The oxidation of polysaccharide hydroxyl groups to carbonyl groups plays an important role in the reduction of selenium salts [108]. The reducing end of polysaccharides can also be used to introduce an amino functionality capable of complexing to and stabilising metallic nanoparticles [109]. Carbohydrates with such amino groups bind tightly to the surface of the SeNPs, giving them a hydrophilic surface. $[87,110]$. These protein loaded SeNPs, show strong potential against bacterial pathogens also showing antioxidant activity. They play important role in the drugs and widely believed to provide important health benefits [87,111-113].

The spherical particles appeared with average size of $530 \mathrm{~nm}$ during present study (Figure 5a). It was an agreement from the previous literature [49,65]. These particles are charged species, the charge is measured by zeta potential. Zeta potential value other than $-30 \mathrm{mV}$ to $+30 \mathrm{mV}$ (depending on the charge) is generally considered to have sufficient repulsive force for the nanoparticles, to remain in the colloidal system. On the other hand, a small zeta potential value can result in particle aggregation and flocculation due to the van der Waals attractive forces act upon them [114,115]. During this research, the recorded zeta potential $(-26.9 \mathrm{mV})$ indicates that these nanoparticles aggregated quickly in the solutions leading to a stable dispersion and can be easily obtained. Same kind of approach was recorded by Fritea et al., (2017) [116]. Moreover, the EPM of SeNPs in water was found $-2.11 \mu \mathrm{m} . \mathrm{cm} /$ Vs. EPM measurement is a powerful technique to estimate the surfaced electrical properties of a charged spherical colloidal particle in a solution $[117,118]$. The high negative charge on the surface of the nanoparticles could also be an indication of the greater stability of the biogenic nanoparticles [50].

The stability of nanoparticles is not only important during any process or treatment but also for their respective function [119]. As the SeNPs purification procedure included alternative sonication $(300 \mathrm{~W})$ with serial treatment followed by washing with various buffers and salt solutions [73]. This technique was used in the present study in order to maintain stability and durability of obtained product (SeNPs).

Spherical and/or amorphous shaped SeNPs, with some aggregates of different lengths were recorded. Same kind of SeNPs were reported in the previous literature for most of the bacteria [120-122]. The sizes and shapes of biogenic metallic nanoparticles can be controlled by exchanging the bio-reduction conditions, including type of culture and organism, nature of the medium and incubation time etc. [120]. The size and shape of the SeNPs were confirmed by transmission electron microscope (TEM) Spherical/amorphous SeNps, deposited on the surface of Bacillus Subtilis BSN313 (Figure 6a,b). The process of formation of SeNPs (spherical/amorphous) was in agreement with Srivastava et al., (2013) [2]. Scanning electron microscopy with energy dispersive X-ray spectroscopy (SEMEDS) is a widely accepted technique for the analysis of these biogenic particles, with the 
presence of selenium in them and display spectroscopic maps by showing the elemental distribution of SeNPs obtained by TEM imaging. The recorded image from SEM-EDS (Figure 6c,d), showing the elemental distribution of Se in the SeNPs.

Selenium nanoparticles (SeNPs) are attracting much attention for their excellent biological activities and low toxicity. Many studies have revealed that the SeNPs exhibited novel antioxidant activities in vitro and in vivo by the activation of selenoenzymes [34,123-127]. In the present study, SeNPs produced at 24 and 48 h shown (Table 1) some good antioxidant (DPPH and ABTS scavenging) activities. Exopolysaccharide-capped SeNPs synthesized by Bacillus paralicheniformis SR14 were also found with better antioxidant properties on scavenging DPPH and ABTS free radicals at the concentration $\geq 1 \mathrm{mM}$ [128]. Whereas, Forootanfar et al., (2014) [68] reported the moderate DPPH and ABTS free radicals scavenging effect of SeNPs produced by Bacillus sp. MSh- 1 at the concentration of $\geq 120 \mu \mathrm{g} / \mathrm{mL}$. In the same way, Greeshma and Mahesh, (2019) [129] reported SeNPs, emerged via Bacillus species as good antioxidant substitutions by DPPH assay at the $\mathrm{IC}_{50}$ value of $11.6 \mu \mathrm{g} / \mathrm{mL}$.

SeNPs formed at 24 and $48 \mathrm{~h}$ also shown a substantial growth inhibition at a concentration of $200 \mu \mathrm{g} / \mathrm{mL}$ against E. coli, P. aeruginosa and S. aureus. Srivastava and Mukhopadhyay, (2015) [52] reported, 99\% inhibition of SeNPs at $250 \mu \mathrm{g} / \mathrm{mL}$ against, E. coli, P. aeruginosa, S. aureus and S. pyogenes. Similarly, Geoffrion et al., (2020) [130] also reported SeNPs as good antimicrobial agents against MDR E. coli, P. aeruginosa, S. epidermidis, and MRSA. Likewise, SeNPs produce via B. amyloliquefaciens SRB04 had shown a remarkable antibacterial activity on S. aureus compared with broad-spectrum antibiotic chloramphenicol [97]. It is already discussed in detail that the surface of the SeNPs is loaded by carbohydrates plus protein complex structure, showing strong potential against bacterial pathogens also having antioxidant activity.

The antioxidant and antibacterial activities of SeNPs synthesized by other species of Bacillus strain were also recorded. The SeNPs synthesized by B. amyloliquefaciens, have no bactericidal activity against $E$. coli PTCC 1329 while giving significant antibacterial activity against S. aureus PTCC 1112 (ZOI: $18.6 \mathrm{~mm}$ ) [97]. The SeNPs synthesized by B. laterosporus, have higher zone of inhibition (ZOI) against E. coli $(22 \mathrm{~mm})$ and S. aureus $(37 \mathrm{~mm})$ [131]. The nanoparticles made by Bacillus cereus and Bacillus species Msh-1 have antioxidant activity [50,132].

\section{Material and Methods}

\subsection{Equipment Used}

Shaking incubator (Model No. IFORS AG CH-4103) made in Bottmingen Switzerland, High-Pressure Steam Autoclave (Model No. HVA-100) made by Hirayama, Japan. pH Meter (Model No. FE20) equipped with InLab Pure Pro-ISM probe made by Mettler Instruments Shanghai Co. Ltd. Freeze dryer (Model No. ALPHA 1-4 LSC) made by Martin Christ. Multimode Microplate Reader (Model No. Infinite M200 PRO) made by Tecan in Switzerland, Microscope (Model No. CX31 Japan Olympus Corporation), FTIR (FTS-65, Bio Rad, USA) Zetasizer Nano Series (Malvern, UK). Scan Electron Microscope coupled with EDS (JEOL JSM-IT 100, Japan); Transmission Electron Microscopy (JEOL JEM-1010, JEOL, Peabody, MA, USA).

\subsection{Supplies and Chemicals}

Analytical grade $\mathrm{Na}_{2} \mathrm{SeO}_{3}(\geq 99.0 \%), \mathrm{HCl}(\geq 37 \%)$, Glucose anhydrous $(\geq 99.0 \%)$, Sucrose anhydrous $(\geq 99.0 \%), \mathrm{NaCl}(\geq 99.0 \%), \mathrm{KCl}, \mathrm{MgSO}_{4} \times 7 \mathrm{H}_{2} \mathrm{O}(\geq 98.0 \%)$, TrisHCl $(\geq 99.0 \%), \mathrm{NaOH}(\geq 98.0 \%), \mathrm{Na}_{2} \mathrm{~S}(\geq 99.0 \%), \mathrm{Na}_{2} \mathrm{HPO}_{4} \times 12 \mathrm{H}_{2} \mathrm{O}(\geq 99.0 \%)$ and $\mathrm{KH}_{2} \mathrm{PO}_{4}$ $(\geq 99.5 \%)$, were purchased from Sinopharm Chemical Reagent Co. Ltd, China. Biological grade peptone was acquired from Beijing Aoboxing Biotechnology Co. Ltd. Biological grade agar was produced by the Beijing Kangbeisi Technology Co. Ltd. Yeast Extract LP0021 was from Oxoid, made in France. Potassium persulfate ( $\geq 99.0 \%)$ and 2,2-Diphenyle1-picrylhydrazyl (DPPH, $\geq 95.0 \%$ ) were purchased from Sigma-Aldrich. 


\subsection{Preparation of Common Solutions and Medium}

A stock solution of Se $(50 \mathrm{mg} / \mathrm{mL})$ was prepared by exactly weighing $5.475 \mathrm{~g}$ of sodium selenite $\left(\mathrm{Na}_{2} \mathrm{SeO}_{3}\right)$, dissolved and diluted up to $50 \mathrm{~mL}$ with deionized water, and the solution was sterilized by passing it through a $0.22 \mu \mathrm{m}$ syringe filter.

LB (Luria Broth) was prepared by adding $0.5 \mathrm{~g}$ yeast extract, $1 \mathrm{~g}$ peptone, and $1 \mathrm{~g}$ $\mathrm{NaCl}$, to $100 \mathrm{~mL}$ distilled water and adjusted the $\mathrm{pH}$ to 7.0 , consuming $1 \mathrm{M} \mathrm{HCl}$. LB solid medium was prepared by adding $1.5 \mathrm{~g}$ agar to the LB medium and autoclaved at $121^{\circ} \mathrm{C}$ for $15 \mathrm{~min}$. An appropriate volume of hot medium was poured into sterilized petri plates and then allowed to solidify. The required concentration of Se was achieved by adding filtered sterilized stock solution in hot LB medium.

\subsection{SeNPs Synthesizing Capability}

\subsubsection{Strain Activation and Preparation of Inoculum}

Bacillus Subtilis BSN313previously isolated from traditional Chinese "Jiuqu" [94] was used in this study.Strain (frozen at $-80^{\circ} \mathrm{C}$ ) was thawed on ice and streaked on LB medium plates, by means of an inoculation loop and incubated at $37^{\circ} \mathrm{C}$ for $12 \mathrm{~h}$. A single colony was inoculated into a pre-sterilized $10 \mathrm{~mL}$ tube containing $4 \mathrm{~mL}$ of LB broth and grown at $37^{\circ} \mathrm{C}$ for $12 \mathrm{~h}$ at $220 \mathrm{rpm}$ shaking speed.

\subsubsection{Selenium Reducing Capability}

Initially, the inoculum was streaked on LB medium with $(1-10 \mu \mathrm{g} / \mathrm{mL})$ and without selenium (control) in order to check the Se reducing capability. The appearance of reddish colonies in the presence of Se was the first evidence for Se reducing ability.

Added $1 \mathrm{~mL}$ of inoculum in a $250 \mathrm{~mL}$ flask containing $100 \mathrm{~mL}$ of sterilized LB medium. Supplemented a required volume of sodium selenite $(50 \mathrm{mg} / \mathrm{mL})$ solution to contribute $5,10,20,30,60,100,150,200,250,350,450$ and $600 \mu \mathrm{g} / \mathrm{mL}$ of Se in the medium. Grown in shaking incubator at $37^{\circ} \mathrm{C}$ for 24 and $48 \mathrm{~h}$ at $200 \mathrm{rpm}$. The total reduce Se $\left(\mathrm{S}^{0}\right)$ was determined in each flask and calculated the percent Se reduction capability of BSN313.

The production of extracellular selenium nano-spheres $\left(\mathrm{SeNPs}\right.$ as $\mathrm{S}^{0}$ ) were preliminarily confirmed by color (reddish) change followed by observing the culture suspension (Figure 3a) under the microscope (Model No. CX31 Japan Olympus Corporation).

\subsubsection{Determination of Reduced Selenium}

Exactly, $20 \mathrm{~mL}$ of bacterial red-coloured culture was taken from the flasks comprising different Se concentrations ( 5 to $600 \mu \mathrm{g} / \mathrm{mL}$ ). Centrifuged at $8000 \mathrm{rpm}$ for $10 \mathrm{~min}$ and in order to remove non-metabolized selenite, the pellets were washed twice with $20 \mathrm{~mL}$ of $1 \mathrm{M} \mathrm{NaCl}$. The red colloidal Se in the pellet was dissolved in $2 \mathrm{~mL}$ of $1 \mathrm{M} \mathrm{Na}_{2} \mathrm{~S}$ and then centrifuged to eliminate bacterial cells debris. A calibration curve $\left(R^{2}=0.995\right)$ was made using the method adopted by Mishra et al., (2011) [73] with some modifications. 125-950 $\mu \mathrm{g}$ of seleniumas sodium selenite was chemically reduced using $40 \mu \mathrm{L}$ of $1 \mathrm{M} \mathrm{HN}_{2} \mathrm{OH} \cdot \mathrm{HCl}$ in a total of $400 \mu \mathrm{L}$ reaction system volume. The contents were allowed to stand for $1 \mathrm{~h} 37^{\circ} \mathrm{C}$ temperature and then dried under the stream of $\mathrm{N}_{2}$. Add $2 \mathrm{~mL}$ of $1 \mathrm{MNa}_{2} \mathrm{~S}$ solution to each tube, mixed and the intensity of the red-brown was read at $500 \mathrm{~nm}$.

\subsubsection{Final Production of SeNPs}

SeNPs were prepared (in bulk for characterization/application) in $1 \mathrm{~L}$ shaking flask containing $250 \mathrm{~mL}$ LB medium along with $200 \mu \mathrm{g} / \mathrm{mL}$ of selenium. A $1 \mathrm{~mL}$ of BSN313 inoculum was added and allowed to grow in a shaking incubator at $37^{\circ} \mathrm{C}$ and $200 \mathrm{rpm}$ for $24 \mathrm{~h}$.

SeNPs were purified by the procedure adopted by Mishra et al., (2011) [73] with some amendments. The red colour bacterial culture was centrifuged at $8000 \mathrm{rpm}$ for $5 \mathrm{~min}$ and collected the pellet. Added $30 \mathrm{~mL}$ of $0.5 \mathrm{M} \mathrm{NaCl}$ to proximately $1 \mathrm{~g}$ pellet and ultra-sonicate at $300 \mathrm{~W}$ for $10 \mathrm{~min}$. Centrifuge for $5 \mathrm{~min}$ at $8000 \mathrm{rpm}$. The pellets were re-suspend and centrifuge successively in $0.5 \mathrm{M} \mathrm{NaCl}, 0.5 \mathrm{M}$ sucrose, and finally a complete salts solution 
containing $17.5 \mathrm{~g} \mathrm{NaCl}, 0.74 \mathrm{~g} \mathrm{KCl} 12.3 \mathrm{~g} \mathrm{MgSO}_{4} \times 7 \mathrm{H}_{2} \mathrm{O}$ and $0.15 \mathrm{~g}$ of TrisHCl per liter, adjusted the $\mathrm{pH}$ to 7.5 . The cells were lysed in $30 \mathrm{~mL}$ of $0.057 \%$ lysozyme solution in complete salts. The lysed cells were washed away from the nanoparticles by sequential re-suspension and ultra-sonication and centrifugation $(8000 \mathrm{rpm})$ in $30 \mathrm{~mL}$ of complete salts solution, $0.25 \mathrm{M} \mathrm{NaOH}, 0.1 \mathrm{M} \mathrm{NaOH}, 10 \mathrm{mM} \mathrm{Na}_{2} \mathrm{HPO}_{4}$ (pH 7.3), distilled and deionized water. Lastly, the SeNPs were re-suspended in deionized water. To ensure the purification of SeNPs, final solution was observed in microscope (Figure 3b) at a magnification of $400 \times$. For further characterization, the purified SeNPs were freeze dry at $0.12 \mathrm{mbr}$ and $-40{ }^{\circ} \mathrm{C}$ for $24 \mathrm{~h}$.

\subsection{Characterization of SeNPS}

\subsubsection{UV/visible and FTIR Spectral Analysis}

Suspension of purified SeNPs was made in deionized water and then the UV visible spectra was recorded range between 200-800nm using a multimode microplate reader (Infinite M200 PRO). While FTIR spectra $\left(4000 \sim 400 \mathrm{~cm}^{-1}\right)$ was noted through FTS-65, Bio Rad using freeze-dried powder of purified SeNPs.

\subsubsection{Particle Size, Zeta Potential and Electrophilic Mobility Measurements}

Zeta Potential (ZP), size distribution, and electrophilic mobility (EM) were conducted through Zetasizer Nano Series (Malvern). SeNPs were dispersed in deionized water and sonicated for $8 \mathrm{~min}$ then around $0.5 \mathrm{~mL}$ of the suspension was transferred to the cuvette of dip cell kit for particle size distribution ZP and EM.

\subsubsection{Transmission Electron Microscopy}

JEOL JEM-1010 Transmission Electron Microscope (TEM) was used to understand the morphological appearance. Purified SeNPs were suspended in deionized water and deposited a drop of suspension on a carbon-coated copper grid and dried at room temperature. TEM was operated to visualized the SeNPs at the accelerating voltage of $100 \mathrm{kV}$ at $0.4 \mathrm{~nm}$ point to point resolution.

\subsubsection{Scan Electron Microscopy EDS}

Scanning electron microscopy (SEM) coupled EDS was used to morphological and elemental composition of SeNPs. Nanoparticles (Se) were sterilized by ultraviolet light in laminar air flow. The sterilized nanoparticles were carefully mounted on SEM stubs by using adhesive tape and uniformly coated with carbon (JEOL-EC-32010CC) and placed in a sample chamber of SEM-EDS (JEOL JSM-IT 100, Japan) and scanning was performed under different magnifications_-ranging from $\times 6000$ to $\times 8000$ - and a voltage of $20 \mathrm{kV}$.

\subsection{Bioactivities of SeNPS}

\subsubsection{DPPH Scavenging Assay}

For the DPPH scavenging assay, the method of Lee et al., (2015) [82] was followed with some amendments. Briefly, $150 \mu \mathrm{L}$ of DPPH solution $(0.08 \mathrm{mg} / \mathrm{mL}$ ethanol $)$ and $50 \mu \mathrm{L}$ sample $(150 \mu \mathrm{g} / \mathrm{mL})$ were mixedin a well of96-well plate (in triplicate). $50 \mu \mathrm{L}$ distilled water was used instead of the sample as a control group, and anhydrous ethanol was used instead of DPPH solvent as a blank group. The plate was kept in dark for 90 min and then absorbance was measured at $514 \mathrm{~nm}$.

$$
\text { DPPH free radical scavenging rate }(\%)=\frac{\text { A control group }- \text { A sample group }}{\text { A control group }- \text { A blank group }} \times 100
$$

\subsubsection{ABTS Scavenging Assay}

ABTS scavenging assay was performed using the method adopted by Lee et al., (2015) [133] with some modifications. Briefly, 7 micro moles ABTS was made in a solution of potassium persulfate $(140 \mathrm{mM})$, protected from light for $10 \mathrm{~min}$, diluted with PBS (pH 7.4, $0.1 \mathrm{M})$ to its absorbance $1.0 \pm 0.02$ at $734 \mathrm{~nm}$. A $150 \mu \mathrm{L}$ ABTS was placed in per well of 
96-well plate (in triplicate) and added $50 \mu \mathrm{L}$ sample $(150 \mu \mathrm{g} / \mathrm{mL}) .50 \mu \mathrm{L}$ distilled water was used instead of the sample as a control group and $50 \mu \mathrm{L}$ of ABTS solvent (PBS, pH 7.4, $0.1 \mathrm{M}$ ) was used as a blank group. The plate was kept in dark for 40 min and absorbance was measured at $734 \mathrm{~nm}$.

$$
\text { ABTS free radical scavenging rate }(\%)=\frac{\text { A control group }- \text { A sample group }}{\text { A control group }- \text { A blank group }} \times 100
$$

\subsubsection{Antimicrobial Activity}

The antibacterial activities of the SeNPs were examined against E. coli ATCC 8739, S. aureus ATCC 25923, and P. aeruginosa ATCC 9027 in tryptone soya agar (TSA). The overnight cultures of the subject isolate were inoculated on TSA Plate. Various concentrations (100, 150 and $200 \mu \mathrm{g} / \mathrm{mL}$ ) of SeNPs were applied. The inhibition zone around SeNPs spots were measured after $24 \mathrm{~h}$ of incubation at $35^{\circ} \mathrm{C}$.

\section{Conclusions}

A growing need for sustainability initiatives in the field of nanotechnology has brought about the development of biogenic procedures for the synthesis of SeNPs-a development which is rapidly replacing traditional chemical syntheses. This transition has many advantages, including the decreased use of chemicals that are toxic to our health and the environment, and the creation of a collection of nanocomposites with many novel applications in nanobiotechnology. The characterization and bioactivities of SeNPs confirmed adequate composition and viability of the produced SeNPs against bacterial pathogens, as well as good antioxidant activity. The results of this study could have a great impact due to the simple culture requirements for BSN313, with an accordingly low production cost of biologically important SeNPs. Therefore, with these potential biological impacts, the tested SeNPs have a tremendous potential for application in the pharmaceutical, biomedical, and food industries, and especially as antimicrobial and antioxidant agents. Further studies are necessary in order to demonstrate possible medical and biological applications, such as in food supplements and pharmaceuticals.

Author Contributions: Conceptualization, M.W.H.C.; Data curation, Z.A.M., M.U. and N.A.; Formal analysis, A.A.; Funding acquisition, F.W and B.X. (Baocai Xu); Investigation, X.Y. and B.X. (Bo Xu); Methodology, A.U.; Project administration, F.W. and B.X. (Baocai Xu); Supervision, F.W.; Validation, A.U.; Visualization, M.N.; Writing—original draft, A.U.; Writing—review \& editing, M.W.H.C. All authors have read and agreed to the published version of the manuscript.

Funding: Beijing Municipal Education Commission, Beijing Natural Science Foundations, Grant/Award Number: KM201910011005, PXM2019_014213_000007; National Natural Science Foundation of China, Grant/Award Number: 21808005 Central Public-interest Scientific Institution Basal Research Fund, Grant/Award Number: ZX1945.

Data Availability Statement: The data is available on request.

Conflicts of Interest: The authors confirm no conflict of interest.

\section{References}

1. Husen, A.; Siddiqi, K.S. Plants and microbes assisted selenium nanoparticles: Characterization and application. J. Nanobio-Technol. 2014, 12, 28. [CrossRef] [PubMed]

2. Srivastava, N.; Mukhopadhyay, M. Biosynthesis and structural characterization of selenium nanoparticles mediated by Zooglea ramigera. Powder Technol. 2013, 244, 26-29. [CrossRef]

3. Wang, K.Y.; Peng, C.Z.; Huang, J.L.; Huang, Y.D.; Jin, M.C.; Geng, Y. The pathology of selenium deficiency in Cyprinus carpio L. J. Fish Dis. 2013, 36, 609-615. [CrossRef] [PubMed]

4. Monsen, E.R. Dietary Reference Intakes for The Antioxidant Nutrients: Vitamin C, Vitamin E, Selenium, and Carotenoids. J. Am. Diet. Assoc. 2000, 100, 637-640. [CrossRef]

5. Kristal, A.R.; Darke, A.K.; Morris, J.S.; Tangen, C.M.; Goodman, P.J.; Thompson, I.M.; Meyskens, F.L.; Goodman, G.E.; Minasian, L.M.; Parnes, H.L.; et al. Baseline Selenium Status and Effects of Selenium and Vitamin E Supplementation on Prostate Cancer Risk. J. Natl. Cancer Inst. 2014, 106, djt456. [CrossRef] 
6. Vinceti, M.; Filippini, T.; Rothman, K.J. Selenium exposure and the risk of type 2 diabetes: A systematic review and meta-analysis. Eur. J. Epidemiol. 2018, 33, 789-810. [CrossRef] [PubMed]

7. Lavado, R.; Shi, D.; Schlenk, D. Effects of salinity on the toxicity and biotransformation of l-selenomethionine in Japanese medaka (Oryziaslatipes) embryos: Mechanisms of oxidative stress. Aquat. Toxicol. 2012, 108, 18-22. [CrossRef]

8. Lemly, A. Symptoms and implications of selenium toxicity in fish: The Belews Lake case example. Aquat. Toxicol. 2002, 57, 39-49. [CrossRef]

9. Han, H.-W.; Patel, K.; Kwak, J.-H.; Jun, S.-K.; Jang, T.-S.; Lee, S.-H.; Knowles, J.; Kim, H.-W.; Lee, H.-H.; Lee, J.-H. Selenium Nanoparticles as Candidates for Antibacterial Substitutes and Supplements against Multidrug-Resistant Bacteria. Biomolecules 2021, 11, 1028. [CrossRef]

10. Weekley, C.M.; Harris, H.H. Which form is that? The importance of selenium speciation and metabolism in the prevention and treatment of disease. Chem. Soc. Rev. 2013, 42, 8870-8894. [CrossRef]

11. Liu, Q.; Jiang, L.; Tian, J.; Ni, J. The molecular biology of selenoproteins and their effects on diseases. Prog. Chem. 2009, $21,819$.

12. Gao, X.; Jinsong, Z.; Lide, Z. Hollow sphere selenium nanoparticles: Their in-vitro anti hydroxyl radical effect. Adv. Mater. 2002, 14, 290-293. [CrossRef]

13. Fairweather-Tait, S.J.; Bao, Y.; Broadley, M.; Collings, R.; Ford, D.; Hesketh, J.E.; Hurst, R. Selenium in Human Health and Disease. Antioxid. Redox Signal. 2011, 14, 1337-1383. [CrossRef] [PubMed]

14. Skalickova, S.; Milosavljevic, V.; Cihalova, K.; Horky, P.; Richtera, L.; Adam, V. Selenium nanoparticles as a nutritional supplement. Nutrition 2017, 33, 83-90. [CrossRef]

15. Carvalho, C.M.L.; Lu, J.; Zhang, X.; Arnér, E.S.J.; Holmgren, A. Effects of selenite and chelating agents on mammalian thioredoxin reductase inhibited by mercury: Implications for treatment of mercury poisoning. FASEB J. 2011, 25, 370-381. [CrossRef] [PubMed]

16. Feroci, G.; Badiello, R.; Fini, A. Interactions between different selenium compounds and zinc, cadmium and mercury. J. Trace Elem. Med. Biol. 2005, 18, 227-234. [CrossRef] [PubMed]

17. El-Demerdash, F.M. Effects of selenium and mercury on the enzymatic activities and lipid peroxidation in brain, liver, and blood of rats. J. Environ. Sci. Health Part B 2001, 36, 489-499. [CrossRef] [PubMed]

18. Branco, V.; Canário, J.; Lu, J.; Holmgren, A.; Carvalho, C. Mercury and selenium interaction in vivo: Effects on thioredoxin reductase and glutathione peroxidase. Free Radic. Biol. Med. 2012, 52, 781-793. [CrossRef]

19. Yang, R.; He, Y.; Luo, L.; Zhu, M.; Zan, S.; Guo, F.; Wang, B.; Yang, B. The interaction between selenium and cadmium in the soil-rice-human continuum in an area with high geological background of selenium and cadmium. Ecotoxicol. Environ. Saf. 2021, 222, 112516. [CrossRef]

20. Chudobova, D.; Cihalova, K.; Dostalova, S.; Ruttkay-Nedecky, B.; Rodrigo, M.A.M.; Tmejova, K.; Kopel, P.; Nejdl, L.; Kudr, J.; Gumulec, J.; et al. Comparison of the effects of silver phosphate and selenium nanoparticles on Staphylococcus aureusgrowth reveals potential for selenium particles to prevent infection. FEMS Microbiol. Lett. 2014, 351, 195-201. [CrossRef]

21. Li, X.; Xing, M.; Chen, M.; Zhao, J.; Fan, R.; Zhao, X.; Cao, C.; Yang, J.; Zhang, Z.; Xu, S. Effects of selenium-lead interaction on the gene expression of inflammatory factors and selenoproteins in chicken neutrophils. Ecotoxicol. Environ. Saf. 2017, 139, 447-453. [CrossRef] [PubMed]

22. Sharma, A.; Goyal, A.K.; Rath, G. Recent advances in metal nanoparticles in cancer therapy. J. Drug Target. 2018, $26,617-632$. [CrossRef] [PubMed]

23. Adeyemi, O.S.; Sulaiman, F.A. Evaluation of metal nanoparticles for drug delivery systems. J. Biomed. Res. 2015, $29,145$. [CrossRef]

24. Kwon, S.J.; Bard, A.J. DNA Analysis by Application of Pt Nanoparticle Electrochemical Amplification with Single Label Response. J. Am. Chem. Soc. 2012, 134, 10777-10779. [CrossRef] [PubMed]

25. Sun, C.; Lee, J.; Zhang, M. Magnetic nanoparticles in MR imaging and drug delivery. Adv. Drug Deliv. Rev. 2008, 60, 1252-1265. [CrossRef]

26. Doria, G.; Conde, J.; Veigas, B.; Giestas, L.; Almeida, C.; Assunção, M.; Rosa, J.; Baptista, P.V. Noble Metal Nanoparticles for Biosensing Applications. Sensors 2012, 12, 1657-1687. [CrossRef]

27. Vaseashta, A.; Vaclavikova, M.; Gallios, G.; Roy, P.; Pummakarnchana, O. Nanostructures in environmental pollution detection, monitoring, and remediation. Sci. Technol. Adv. Mater. 2007, 8, 47. [CrossRef]

28. Gadad, A.P.; Kumar, S.V.; Dandagi, U.M.; Bolmol, B.; Pallavi, N.P. Nanoparticles and their Therapeutic Applications in Pharmacy. Int. J. Pharm. Sci. Nanotechnol. 2014, 7, 2509-2519. [CrossRef]

29. Khandelwal, A.; Ritika, J. Synthesis of Nanoparticles and their Application in Agriculture. Acta Sci. Agric. 2018, 2, 10-13.

30. Matsui, I. Nanoparticles for Electronic Device Applications: A Brief Review. J. Chem. Eng. Jpn. 2005, 38, 535-546. [CrossRef]

31. Stroyuk, A.L.; Raevskaya, A.E.; Kuchmiy, S.Y.; Dzhagan, V.M.; Zahn, D.R.; Schulze, S. Structural and optical characterization of colloidal Se nanoparticles prepared via the acidic decomposition of sodium selenosulfate. Colloids Surf. A Physicochem. Eng. Asp. 2008, 320, 169-174. [CrossRef]

32. Lin, W.; Zhang, J.; Xu, J.-F.; Pi, J. The Advancing of Selenium Nanoparticles Against Infectious Diseases. Front. Pharmacol. 2021, 12, 1971. [CrossRef]

33. Wadhwani, S.A.; Shedbalkar, U.U.; Singh, R.; Chopade, B.A. Biogenic selenium nanoparticles: Current status and future prospects. Appl. Microbiol. Biotechnol. 2016, 100, 2555-2566. [CrossRef] 
34. Wang, H.; Zhang, J.; Yu, H. Elemental selenium at nano size possesses lower toxicity without compromising the fundamental effect on selenoenzymes: Comparison with selenomethionine in mice. Free Radic. Biol. Med. 2007, 42, 1524-1533. [CrossRef]

35. Torres, S.; Campos, V.L.; León, C.G.; Rodríguez-Llamazares, S.; Rojas, S.; Gonzalez, M.I.Z.; Smith, C.L.; Mondaca, M.A. Biosynthesis of selenium nanoparticles by Pantoeaagglomerans and their antioxidant activity. J. Nanopart. Res. 2012, 14, 1-9. [CrossRef]

36. Maiyo, F.; Singh, M. Selenium nanoparticles: Potential in cancer gene and drug delivery. Nanomedicine 2017, 12, 1075-1089. [CrossRef]

37. Lewinski, N.; Colvin, V.; Drezek, R. Cytotoxicity of Nanoparticles. Small 2008, 4, 26-49. [CrossRef] [PubMed]

38. Hussain, S.M.; Braydich-Stolle, L.K.; Schrand, A.M.; Murdock, R.C.; Yu, K.O.; Mattie, D.M.; Schlager, J.J.; Terrones, M. Toxicity Evaluation for Safe Use of Nanomaterials: Recent Achievements and Technical Challenges. Adv. Mater. 2009, 21, 1549-1559. [CrossRef]

39. Maurer-Jones, M.A.; Bantz, K.C.; Love, A.S.; Marquis, B.J.; Haynes, C.L. Toxicity of therapeutic nanoparticles. Nanomedicine 2009, 4, 219-241. [CrossRef] [PubMed]

40. Pelley, J.L.; Daar, A.S.; Saner, M.A. State of Academic Knowledge on Toxicity and Biological Fate of Quantum Dots. Toxicol. Sci. 2009, 112, 276-296. [CrossRef] [PubMed]

41. Soenen, S.J.; Gil, P.R.; Montenegro, J.-M.; Parak, W.J.; De Smedt, S.C.; Braeckmans, K. Cellular toxicity of inorganic nanoparticles: Common aspects and guidelines for improved nanotoxicity evaluation. Nano Today 2011, 6, 446-465. [CrossRef]

42. Hosnedlova, B.; Kepinska, M.; Skalickova, S.; Fernandez, C.; Ruttkay-Nedecky, B.; Peng, Q.; Baron, M.; Melcova, M.; Opatrilova, R.; Zidkova, J.; et al. Nano-selenium and its nanomedicine applications: A critical review. Int. J. Nanomed. 2018, $13,2107$. [CrossRef]

43. Alam, H.; Khatoon, N.; Khan, M.A.; Husain, S.A.; Saravanan, M.; Sardar, M. Synthesis of Selenium Nanoparticles Using Probiotic Bacteria Lactobacillus acidophilus and Their Enhanced Antimicrobial Activity Against Resistant Bacteria. J. Clust. Sci. 2020, 31, 1003-1011. [CrossRef]

44. Singh, M.; Kumar, M.; Kalaivani, R.; Manikandan, S.; Kumaraguru, A.K. Metallic silver nanoparticle: A therapeutic agent in combination with antifungal drug against human fungal pathogen. BioprocessBiosyst. Eng. 2013, 36, 407-415. [CrossRef]

45. Bali, R.; Harris, A.T. Biogenic Synthesis of Au Nanoparticles Using Vascular Plants. Ind. Eng. Chem. Res. 2010, 49, 12762-12772. [CrossRef]

46. Iranifam, M.; Fathinia, M.; Rad, T.S.; Hanifehpour, Y.; Khataee, A.; Joo, S. A novel selenium nanoparticles-enhanced chemiluminescence system for determination of dinitrobutylphenol. Talanta 2013, 107, 263-269. [CrossRef] [PubMed]

47. Nancharaiah, Y.V.; Lens, P.N.L. Ecology and Biotechnology of Selenium-Respiring Bacteria. Microbiol. Mol. Biol. Rev. 2015, 79, 61-80. [CrossRef]

48. Huang, J.; Li, Q.; Sun, D.; Lu, Y.; Su, Y.; Yang, X.; Wang, H.; Wang, Y.; Shao, W.; He, N.; et al. Biosynthesis of silver and gold nanoparticles by novel sundriedCinnamomumcamphoraleaf. Nanotechnology 2007, 18, 105104. [CrossRef]

49. Zhang, W.; Chen, Z.; Liu, H.; Zhang, L.; Gao, P.; Li, D. Biosynthesis and structural characteristics of selenium nanoparticles by Pseudomonas alcaliphila. Colloids Surf. B Biointerfaces 2011, 88, 196-201. [CrossRef]

50. Dhanjal, S.; Cameotra, S.S. Aerobic biogenesis of selenium nanospheres by Bacillus cereus isolated from coalmine soil. Microb. Cell Factories 2010, 9, 52. [CrossRef]

51. Zheng, S.; Su, J.; Wang, L.; Yao, R.; Wang, D.; Deng, Y.; Wang, R.; Wang, G.; Rensing, C. Selenite reduction by the obligate aerobic bacterium Comamonastestosteroni S44 isolated from a metal-contaminated soil. BMC Microbiol. 2014, 14, 204. [CrossRef]

52. Srivastava, N.; Mukhopadhyay, M. Biosynthesis and Characterization of Gold Nanoparticles Using Zooglearamigera and Assessment of Its Antibacterial Property. J. Clust. Sci. 2015, 26, 675-692. [CrossRef]

53. Kora, A.J.; Rastogi, L. Bacteriogenic synthesis of selenium nanoparticles by Escherichia coli ATCC 35218 and its structural characterisation. IET Nanobiotechnol. 2017, 11, 179-184. [CrossRef]

54. Kim, E.B.; Seo, J.M.; Kim, G.W.; Lee, S.Y.; Park, T.J. In vivo synthesis of europium selenide nanoparticles and related cytotoxicity evaluation of human cells. Enzym. Microb. Technol. 2016, 95, 201-208. [CrossRef] [PubMed]

55. Song, D.; Li, X.; Cheng, Y.; Xiao, X.; Lu, Z.; Wang, Y.; Wang, F. Aerobic biogenesis of selenium nanoparticles by Enterobacter cloacae Z0206 as a consequence of fumarate reductase mediated selenite reduction. Sci. Rep. 2017, 7, 1-10. [CrossRef]

56. Kora, A.J.; Rastogi, L. Biomimetic synthesis of selenium nanoparticles by Pseudomonas aeruginosa ATCC 27853: An approach for conversion of selenite. J. Environ. Manag. 2016, 181, 231-236. [CrossRef]

57. Fesharaki, P.J.; Nazari, P.; Shakibaie, M.; Rezaie, S.; Banoee, M.; Abdollahi, M.; Shahverdi, A.R. Biosynthesis of selenium nanoparticles using Klebsiella pneumoniae and their recovery by a simple sterilization process. Braz. J. Microbiol. 2010, 41, 461-466. [CrossRef] [PubMed]

58. Sasidharan, S.; Balakrishnaraja, R. Comparison studies on the synthesis of selenium nanoparticles by various microorganisms. Int. J. Pure Appl. Biosci. 2014, 2, 112-117.

59. Li, B.; Liu, N.; Li, Y.; Jing, W.; Fan, J.; Li, D.; Zhang, L.; Zhang, X.; Zhang, Z.; Wang, L. Reduction of Selenite to Red Elemental Selenium by Rhodopseudomonas palustris Strain N. PLoS ONE 2014, 9, e95955. [CrossRef] [PubMed]

60. Tam, K.; Ho, C.T.; Lee, J.-H.; Lai, M.; Chang, C.H.; Rheem, Y.; Chen, W.; Hur, H.-G.; Myung, N.V. Growth Mechanism of Amorphous Selenium Nanoparticles Synthesized by Shewanellasp. HN-41. Biosci. Biotechnol. Biochem. 2010, 74, 696-700. [CrossRef] [PubMed] 
61. Fernández-Llamosas, H.; Castro, L.; Blázquez, M.L.; Díaz, E.; Carmona, M. Biosynthesis of selenium nanoparticles by Azoarcus sp. CIB. Microb. Cell Factories 2016, 15, 109. [CrossRef]

62. Khoei, N.S.; Lampis, S.; Zonaro, E.; Yrjälä, K.; Bernardi, P.; Vallini, G. Insights into selenite reduction and biogenesis of elemental selenium nanoparticles by two environmental isolates of Burkholderiafungorum. New Biotechnol. 2017, 34, 1-11. [CrossRef]

63. Cremonini, E.; Zonaro, E.; Donini, M.; Lampis, S.; Boaretti, M.; Dusi, S.; Melotti, P.; Lleo, M.M.; Vallini, G. Biogenic selenium nanoparticles: Characterization, antimicrobial activity and effects on human dendritic cells and fibroblasts. Microb. Biotechnol. 2016, 9, 758-771. [CrossRef]

64. Estevam, E.C.; Griffin, S.; Nasim, M.J.; Denezhkin, P.; Schneider, R.; Lilischkis, R.; Dominguez-Alvarez, E.; Witek, K.; Latacz, G.; Keck, C.; et al. Natural selenium particles from Staphylococcus carnosus: Hazards or particles with particular promise? J. Hazard. Mater. 2017, 324, 22-30. [CrossRef]

65. Eszenyi, P.; Sztrik, A.; Babka, B.; Prokisch, J. Elemental, nano-sized (100-500 nm) selenium production by probiotic lactic acid bacteria. Int. J. Biosci. Biochem. Bioinform. 2011, 1, 148. [CrossRef]

66. Cavalu, S.; Prokisch, J.; Laslo, V.; Vicas, S. Preparation, structural characterisation and release study of novel hybrid microspheres entrapping nanoselenium, produced by green synthesis. IET Nanobiotechnol. 2017, 11, 426-432. [CrossRef]

67. Shoeibi, S.; Mashreghi, M. Biosynthesis of selenium nanoparticles using Enterococcus faecalis and evaluation of their antibacterial activities. J. Trace Elem. Med. Biol. 2017, 39, 135-139. [CrossRef]

68. Forootanfar, H.; Adeli-Sardou, M.; Nikkhoo, M.; Mehrbani, M.; Amirheidari, B.; Shahverdi, A.R.; Shakibaie, M. Antioxidant and cytotoxic effect of biologically synthesized selenium nanoparticles in comparison to selenium dioxide. J. Trace Elem. Med. Biol. 2014, 28, 75-79. [CrossRef] [PubMed]

69. Shakibaie, M.; Khorramizadeh, M.; Faramarzi, M.A.; Sabzevari, O.; Shahverdi, A.R. Biosynthesis and recovery of selenium nanoparticles and the effects on matrix metalloproteinase-2 expression. Biotechnol. Appl. Biochem. 2010, 56, 7-15. [CrossRef] [PubMed]

70. Wang, T.; Yang, L.; Zhang, B.; Liu, J. Extracellular biosynthesis and transformation of selenium nanoparticles and application in H2O2 biosensor. Colloids Surf. B Biointerfaces 2010, 80, 94-102. [CrossRef] [PubMed]

71. Piacenza, E.; Presentato, A.; Zonaro, E.; Lemire, J.A.; Demeter, M.; Vallini, G.; Turner, R.J.; Lampis, S. Antimicrobial activity of biogenically produced spherical Se-nanomaterials embedded in organic material against Pseudomonas aeruginosa and Staphylococcus aureus strains on hydroxyapatite-coated surfaces. Microb. Biotechnol. 2017, 10, 804-818. [CrossRef] [PubMed]

72. Sonkusre, P.; Cameotra, S.S. Biogenic selenium nanoparticles induce ROS-mediated necroptosis in PC-3 cancer cells through TNF activation. J. Nanobiotechnol. 2017, 15, 1-12. [CrossRef] [PubMed]

73. Mishra, R.R.; Prajapati, S.; Das, J.; Dangar, T.K.; Das, N.; Thatoi, H. Reduction of selenite to red elemental selenium by moderately halotolerant Bacillus megaterium strains isolated from Bhitarkanika mangrove soil and characterization of reduced product. Chemosphere 2011, 84, 1231-1237. [CrossRef] [PubMed]

74. Tan, Y.; Yao, R.; Wang, R.; Wang, D.; Wang, G.; Zheng, S. Reduction of selenite to Se(0) nanoparticles by filamentous bacterium Streptomyces sp. ES2-5 isolated from a selenium mining soil. Microb. Cell Factories 2016, 15, 157. [CrossRef] [PubMed]

75. Kumar, K.N.; Venkataramana, M.; Allen, J.A.; Chandranayaka, S.; Murali, H.S.; Batra, H.V. Role of Curcuma longa L. essential oil in controlling the growth and zearalenone production of Fusarium graminearum. LWT 2016, 69, 522-528. [CrossRef]

76. Sellamani, M.; Kalagatur, N.K.; Siddaiah, C.; Mudili, V.; Krishna, K.; Natarajan, G.; Putcha, V.L.R. Antifungal and Zearalenone Inhibitory Activity of Pediococcuspentosaceus Isolated from Dairy Products on Fusarium graminearum. Front. Microbiol. 2016, 7, 890. [CrossRef]

77. Kokila, K.; Elavarasan, N.; Sujatha, V. Diospyros montana leaf extract-mediated synthesis of selenium nanoparticles and their biological applications. New J. Chem. 2017, 41, 7481-7490. [CrossRef]

78. Tran, P.A.; O'Brien-Simpson, N.; Reynolds, E.C.; Pantarat, N.; Biswas, D.P.; O'Connor, A. Low cytotoxic trace element selenium nanoparticles and their differential antimicrobial properties againstS.aureusandE. coli. Nanotechnology 2015, 27, 045101. [CrossRef]

79. Gunti, L.; Dass, R.S.; Kalagatur, N.K. Phytofabrication of Selenium Nanoparticles from Emblica officinalis Fruit Extract and Exploring Its Biopotential Applications: Antioxidant, Antimicrobial, and Biocompatibility. Front. Microbiol. 2019, $10,931$. [CrossRef] [PubMed]

80. Castillo-Henriquez, L.; Alfaro-Aguilar, K.; Ugalde-Alvarez, J.; Vega-Fernandez, L.; Montes de Oca-Vasquez, G.; Vega-Baudrit, J.R. Green Synthesis of Gold and Silver Nanoparticles from Plant Extracts and Their Possible Applications as Antimicrobial Agents in the Agricultural Area. Nanomaterials 2020, 10, 1763. [CrossRef]

81. Singh, A.; Gautam, P.K.; Verma, A.; Singh, V.; Shivapriya, P.M.; Shivalkar, S.; Sahoo, A.K.; Samanta, S.K. Green synthesis of metallic nanoparticles as effective alternatives to treat antibiotics resistant bacterial infections: A review. Biotechnol. Rep. 2020, 25, e00427. [CrossRef]

82. Fahmy, S.; Preis, E.; Bakowsky, U.; Azzazy, H. Platinum Nanoparticles: Green Synthesis and Biomedical Applications. Materials 2020, 13, 3661. [CrossRef]

83. Ranjitha, V. Extracellular Synthesis of Selenium Nanoparticles from an Actinomycetes Streptomyces griseoruber and Evaluation of its Cytotoxicity on HT-29 Cell Line. Pharm. Nanotechnol. 2018, 6, 61-68. [CrossRef] [PubMed]

84. Kumar, S.; Tomar, M.S.; Acharya, A. Carboxylic group-induced synthesis and characterization of selenium nanoparticles and its anti-tumor potential on Dalton's lymphoma cells. Colloids Surf. B Biointerfaces 2015, 126, 546-552. [CrossRef] [PubMed] 
85. Ren, Y.; Zhao, T.; Mao, G.; Zhang, M.; Li, F.; Zou, Y.; Yang, L.; Wu, X. Antitumor activity of hyaluronic acid-selenium nanoparticles in Heps tumor mice models. Int. J. Biol. Macromol. 2013, 57, 57-62. [CrossRef]

86. Liu, W.; Li, X.; Wong, Y.-S.; Zheng, W.; Zhang, Y.; Cao, W.; Chen, T. Selenium Nanoparticles as a Carrier of 5-Fluorouracil to Achieve Anticancer Synergism. ACS Nano 2012, 6, 6578-6591. [CrossRef] [PubMed]

87. Park, Y.; Hong, Y.; Weyers, A.; Kim, Y.; Linhardt, R. Polysaccharides and phytochemicals: A natural reservoir for the green synthesis of gold and silver nanoparticles. IET Nanobiotechnol. 2011, 5, 69-78. [CrossRef]

88. Nie, T.; Wu, H.; Wong, K.-H.; Chen, T. Facile synthesis of highly uniform selenium nanoparticles using glucose as the reductant and surface decorator to induce cancer cell apoptosis. J. Mater. Chem. B 2016, 4, 2351-2358. [CrossRef]

89. Instruments, M. Zeta potential: An Introduction in $30 \mathrm{~min}$. Zetasizer Nano Serles Tech. Note. MRK654 2011, 1, 1-6.

90. Předota, M.; Machesky, M.L.; Wesolowski, D.J. Molecular Origins of the Zeta Potential. Langmuir 2016, 32, 10189-10198. [CrossRef]

91. Yang, J.; Yang, H. Recent development in Se-enriched yeast, lactic acid bacteria and bifidobacteria. Crit. Rev. Food Sci. Nutr. 2021, 1-15. [CrossRef]

92. Lampis, S.; Zonaro, E.; Bertolini, C.; Bernardi, P.; Butler, C.S.; Vallini, G. Delayed formation of zero-valent selenium nanoparticles by Bacillus mycoides SeITE01 as a consequence of selenite reduction under aerobic conditions. Microb. Cell Factories 2014, 13, 35. [CrossRef] [PubMed]

93. Kousha, M.; Yeganeh, S.; Amirkolaie, A.K. Effect of sodium selenite on the bacteria growth, selenium accumulation, and selenium biotransformation in Pediococcusacidilactici. Food Sci. Biotechnol. 2017, 26, 1013-1018. [CrossRef] [PubMed]

94. Ullah, A.; Sun, B.; Wang, F.; Yin, X.; Xu, B.; Ali, N.; Mirani, Z.A.; Mehmood, A.; Naveed, M. Isolation of selenium-resistant bacteria and advancement under enrichment conditions for selected probiotic Bacillus subtilis (BSN313). J. Food Biochem. 2020, 44 , e13227. [CrossRef]

95. Tymoshok, N.O.; Kharchuk, M.S.; Kaplunenko, V.G.; Bityutskyy, V.S.; Tsekhmistrenko, S.I.; Tsekhmistrenko, O.S.; Spivak, M.Y.; Melnichenko, O.M. Evaluation of effects of selenium nanoparticles on Bacillus subtilis. Regul. Mech. Biosyst. 2019, 10, 544-552. [CrossRef]

96. Prasad, K.S.; Vaghasiya, J.V.; Soni, S.; Patel, J.; Patel, R.; Kumari, M.; Jasmani, F.; Selvaraj, K. Microbial Selenium Nanoparticles (SeNPs) and Their Application as a Sensitive Hydrogen Peroxide Biosensor. Appl. Biochem. Biotechnol. 2015, 177, $1386-1393$. [CrossRef] [PubMed]

97. Ashengroph, M.; Hosseini, S.-R. A newly isolated Bacillus amyloliquefaciens SRB04 for the synthesis of selenium nanoparticles with potential antibacterial properties. Int. Microbiol. 2021, 24, 103-114. [CrossRef] [PubMed]

98. Al-Otaibi, S. Eco-Friendly Fabrication of Selenium Nanoparticles by Solidstate Thermal Decomposition of SeCl 4-L-Glutamine Precursor: Spectroscopic Characterizations. Spectrosc. Spectr. Anal. 2020, 40, 3644.

99. Keskin, N.O.S.; Vural, O.A.; Abaci, S. Biosynthesis of Noble Selenium Nanoparticles from Lysinibacillus sp. NOSK for Antimicrobial, Antibiofilm Activity, and Biocompatibility. Geomicrobiol. J. 2020, 37, 919-928. [CrossRef]

100. Sowndarya, P.; Ramkumar, G.; Shivakumar, M.S. Green synthesis of selenium nanoparticles conjugated Clausena dentata plant leaf extract and their insecticidal potential against mosquito vectors. Artif. Cells Nanomed. Biotechnol. 2017, 45, 1490-1495. [CrossRef]

101. Alnassar, H.S.; Helal, M.H.; Askar, A.A.; Masoud, D.M.; Abdallah, A.E. Pyridine azo disperse dye derivatives and their selenium nanoparticles (SeNPs): Synthesis, fastness properties, and antimicrobial evaluations. Int. J. Nanomed. 2019, 14, 7903-7918. [CrossRef]

102. Boroumand, S.; Safari, M.; Shaabani, E.; Shirzad, M.; Faridi-Majidi, R. Selenium nanoparticles: Synthesis, characterization and study of their cytotoxicity, antioxidant and antibacterial activity. Mater. Res. Express 2019, 6, 0850d8. [CrossRef]

103. Garbisu, C.; Ishii, T.; Leighton, T.; Buchanan, B.B. Bacterial reduction of selenite to elemental selenium. Chem. Geol. 1996, 132, 199-204. [CrossRef]

104. Klonowska, A.; Heulin, T.; Vermeglio, A. Selenite and Tellurite Reduction by Shewanellaoneidensis. Appl. Environ. Microbiol. 2005, 71, 5607-5609. [CrossRef]

105. Ramya, S.; Shanmugasundaram, T.; Balagurunathan, R. Biomedical potential of actinobacterially synthesized selenium nanoparticles with special reference to anti-biofilm, anti-oxidant, wound healing, cytotoxic and anti-viral activities. J. Trace Elem. Med. Biol. 2015, 32, 30-39. [CrossRef]

106. Mehta, H.; Gupta, M.; Kaur, P.; Kaur, J.; Kaushal, A.N. Redox Modulatory Anti-Inflammatory Potential of Hempseed (Cannabis sativa) based Green Selenium Nanoparticles. Appl. Sci. Converg. Technol. 2021, 30, 81-86. [CrossRef]

107. Alvi, G.B.; Iqbal, M.S.; Ghaith, M.M.S.; Haseeb, A.; Ahmed, B.; Qadir, M.I. Biogenic selenium nanoparticles (SeNPs) from citrus fruit have anti-bacterial activities. Sci. Rep. 2021, 11, 1-11. [CrossRef]

108. Mata, Y.; Torres, E.; Blázquez, M.; Ballester, A.; González, F.; Muñoz, J.A. Gold(III) biosorption and bioreduction with the brown alga Fucus vesiculosus. J. Hazard. Mater. 2009, 166, 612-618. [CrossRef]

109. Nadkarni, V.; Pervin, A.; Linhardt, R. Directional Immobilization of Heparin onto Beaded Supports. Anal. Biochem. 1994, 222, 59-67. [CrossRef] [PubMed]

110. Kemp, M.M.; Kumar, A.; Mousa, S.; Dyskin, E.; Yalcin, M.; Ajayan, P.; Linhardt, R.J.; Mousa, S.A. Gold and silver nanoparticles conjugated with heparin derivative possess anti-angiogenesis properties. Nanotechnology 2009, 20, 455104. [CrossRef]

111. Lamoral-Theys, D.; Pottier, L.; Dufrasne, F.; Neve, J.; Dubois, J.; Kornienko, A.; Kiss, R.; Ingrassia, L. Natural Polyphenols that Display Anticancer Properties through Inhibition of Kinase Activity. Curr. Med. Chem. 2010, 17, 812-825. [CrossRef] 
112. Chen, D.; Dou, Q.P. Tea Polyphenols and Their Roles in Cancer Prevention and Chemotherapy. Int. J. Mol. Sci. 2008, 9, $1196-1206$. [CrossRef] [PubMed]

113. Baldwin, A.D.; Kiick, K.L. Polysaccharide-modified synthetic polymeric biomaterials. Pept. Sci. Orig. Res. Biomol. 2010, 94, 128-140. [CrossRef]

114. Ye, X.; Chen, Z.; Zhang, Y.; Mu, J.; Chen, L.; Li, B.; Lin, X. Construction, characterization, and bioactive evaluation of nano-selenium stabilized by green tea nano-aggregates. LWT 2020, 129, 109475. [CrossRef]

115. Tso, C.-P.; Zhung, C.-M.; Shih, Y.-H.; Tseng, Y.-M.; Wu, S.-C.; Doong, R.-A. Stability of metal oxide nanoparticles in aqueous solutions. Water Sci. Technol. 2010, 61, 127-133. [CrossRef]

116. Fritea, L.; Laslo, V.; Cavalu, S.; Costea, T.; Vicas, S.I. Green biosynthesis of selenium nanoparticles using parsley (Petroselinum crispum) leaves extract. Studia Univ. Vasile Goldis Arad. Ser. Stiintele Vietii Life Sci. Ser. 2017, 27, $203-208$.

117. Kumar, A.; Dixit, C.K. Methods for Characterization of Nanoparticles. In Advances in Nanomedicine for the Delivery of Therapeutic Nucleic Acids; Woodhead Publishing: Cambridge, UK, 2017; pp. 43-58.

118. Makino, K.; Ohshima, H. Electrophoretic Mobility of a Colloidal Particle with Constant Surface Charge Density. Langmuir 2010, 26, 18016-18019. [CrossRef]

119. Phan, H.; Haes, A.J. What Does Nanoparticle Stability Mean? J. Phys. Chem. C 2019, 123, 16495-16507. [CrossRef]

120. Vetchinkina, E.; Loshchinina, E.; Kupryashina, M.; Burov, A.; Nikitina, V. Shape and Size Diversity of Gold, Silver, Selenium, and Silica Nanoparticles Prepared by Green Synthesis Using Fungi and Bacteria. Ind. Eng. Chem. Res. 2019, 58, 17207-17218. [CrossRef]

121. Guisbiers, G.; Wang, Q.; Khachatryan, E.; Mimun, L.; Mendoza-Cruz, R.; Larese-Casanova, P.; Webster, T.; Nash, K. Inhibition of E. coli and S. aureus with selenium nanoparticles synthesized by pulsed laser ablation in deionized water. Int. J. Nanomed. 2016, 11,3731-3736. [CrossRef]

122. Sarkar, J.; Dey, P.; Saha, S.; Acharya, K. Mycosynthesis of selenium nanoparticles. Micro Nano Lett. 2011, 6, 599-602. [CrossRef]

123. Xiao, Y.; Huang, Q.; Zheng, Z.; Guan, H.; Liu, S. Construction of a Cordyceps sinensis exopolysaccharide-conjugated selenium nanoparticles and enhancement of their antioxidant activities. Int. J. Biol. Macromol. 2017, 99, 483-491. [CrossRef]

124. Zhang, J.; Wang, X.; Xu, T. Elemental Selenium at Nano Size (Nano-Se) as a Potential Chemopreventive Agent with Reduced Risk of Selenium Toxicity: Comparison with Se-Methylselenocysteine in Mice. Toxicol. Sci. 2008, 101, 22-31. [CrossRef]

125. Zhang, J.; Wang, H.; Bao, Y.; Zhang, L. Nano red elemental selenium has no size effect in the induction of seleno-enzymes in both cultured cells and mice. Life Sci. 2004, 75, 237-244. [CrossRef]

126. Peng, D.; Zhang, J.; Liu, Q.; Taylor, E.W. Size effect of elemental selenium nanoparticles (Nano-Se) at supranutritional levels on selenium accumulation and glutathione S-transferase activity. J. Inorg. Biochem. 2007, 101, 1457-1463. [CrossRef]

127. Huang, B.; Zhang, J.; Hou, J.; Chen, C. Free radical scavenging efficiency of Nano-Se in vitro. Free Radic. Biol. Med. 2003, 35, 805-813. [CrossRef]

128. Cheng, Y.; Xiao, X.; Li, X.; Song, D.; Lu, Z.; Wang, F.; Wang, Y. Characterization, antioxidant property and cytoprotection of exopolysaccharide-capped elemental selenium particles synthesized by Bacillus paralicheniformis SR14. Carbohydr. Polym. 2017, 178, 18-26. [CrossRef]

129. Greeshma, B.C.; Mahesh, M. Biosynthesis of selenium nanoparticles from Bacillus species and its applications. J. Appl. Nat. Sci. 2019, 11, 810-815. [CrossRef]

130. Geoffrion, L.D.; Hesabizadeh, T.; Medina-Cruz, D.; Kusper, M.; Taylor, P.; Vernet-Crua, A.; Chen, J.; Ajo, A.; Webster, T.J.; Guisbiers, G. Naked Selenium Nanoparticles for Antibacterial and Anticancer Treatments. ACS Omega 2020, 5, $2660-2669$. [CrossRef]

131. El-Batal, A.I.; Essam, T.M.; El-Zahaby, D.A.; Amin, M.A. Synthesis of Selenium Nanoparticles by Bacillus laterosporus Using Gamma Radiation. Br. J. Pharm. Res. 2014, 4, 1364-1386. [CrossRef]

132. Shakibaie, M.; Mohazab, N.S.; Mousavi, S.A.A. Antifungal Activity of Selenium Nanoparticles Synthesized by Bacillus species Msh-1 Against Aspergillus fumigatus and Candida albicans. Jundishapur J. Microbiol. 2015, 8, e26381. [CrossRef]

133. Lee, K.J.; Oh, Y.C.; Cho, W.K.; Ma, J.Y. Antioxidant and Anti-Inflammatory Activity Determination of One Hundred Kinds of Pure Chemical Compounds Using Offline and Online Screening HPLC Assay. Evid.-Based Complement. Altern. Med. 2015, 2015, 1-13. [CrossRef] [PubMed] 